Transl Endocrinol Metab. 2010 April ; 1(1): 55-86. doi:10.1210/TEAM.9781879225718.ch2.

\title{
Pathogenesis of Osteoporosis
}

\author{
Sundeep Khosla, M.D. \\ Endocrine Research Unit, College of Medicine, Mayo Clinic, Rochester, MN
}

\begin{abstract}
As for most multifactorial disorders, the pathogenesis of osteoporosis is complex, and a different set of mechanisms may be operative in any given individual. However, there are certain common causes of bone loss and increased fracture risk with aging in most people. These include genetic factors contributing to the acquisition of peak bone mass, illnesses affecting skeletal growth and development, sex steroid deficiency following the menopause in women and with aging in men, and intrinsic, age-related changes in bone metabolism. Superimposed on these factors are specific secondary causes of bone loss, such as corticosteroid use or other illnesses affecting bone metabolism that may contribute to fracture risk in individuals exposed to these factors. The past decade has witnessed tremendous advances in our understanding of each of these various causes of bone loss, leading to the development of novel, mechanism-based therapeutic approaches to prevent and treat this important public health disorder.
\end{abstract}

\section{Keywords}

bone loss; fractures; osteoporosis

\section{Introduction}

Osteoporosis is a multifactorial disorder and any model for pathogenesis has to recognize that a different set of mechanisms may be operative in any given individual. However, there are certain common mechanisms that mediate bone loss with aging in most people, although the relative contributions of each of these may vary from person to person. Figure 1 provides an overview of the key factors contributing to bone loss and ultimately, to fracture. Clearly, individuals who fail to attain adequate peak bone mass for any reason (e.g., genetics [discussed in detail in Chapter 3]) or illnesses affecting skeletal growth and development (e.g., anorexia nervosa, corticosteroid use, etc.) may be at increased risk of fracture later in life due to impaired bone mass or bone quality. Following maturity, women will face the skeletal insult of menopause and the attendant bone loss (1); while men do not have an equivalent of the menopause, they do have a more gradual onset of sex steroid deficiency that clearly impacts the skeleton (2). In addition, there is increasing evidence for intrinsic age-related changes in bone metabolism that are similar to changes with age in other tissues and which likely contribute to bone loss independent of sex steroid deficiency. Finally, as

Address all correspondence to Sundeep Khosla, M.D., Guggenheim 7, College of Medicine, Mayo Clinic, 200 First Street SW, Rochester, Minnesota 55905; khosla.sundeep@ mayo.edu.

Disclosure: None 
shown in Figure 1, different individuals in the population, over the course of their lives, will be exposed to potential secondary causes of bone loss, such as glucocorticoid use, thyrotoxicosis, etc., that will accentuate the effects of menopausal or age-related bone loss. Each of these major factors contributing to bone loss and fracture risk, many of which are illustrated by the 3 cases presented at the end of Chapter 1, are considered in more detail in this review.

\section{Patterns of bone mass acquisition and loss in women and men}

\section{Acquisition of peak bone mass}

There is considerable evidence that the bone mass of an individual in later life depends, in large part, on the peak bone mass attained during childhood and adolescent growth. In a unique study of a Finnish cohort, Cooper et al. (3) linked birth and childhood growth data to later hospital discharge records for hip fracture in $~ 7000$ women and men born at the Helsinki University Central Hospital during 1924-1933. In addition to body size at birth, an average of 10 measurements of height and weight throughout childhood were recorded for each subject. After adjustment for age and gender, there were two major determinants of hip fracture risk in late life: tall maternal height $(\mathrm{P}<0.001)$ and low rate of childhood growth (height, $\mathrm{P}=0.006$; weight, $\mathrm{P}=0.01$ ). Further analyses demonstrated that in boys, there was a constant deficit in height and weight between ages 7 and 15 years among those who sustained hip fractures later; in girls, there was a progressively increasing deficit in weight but a delayed height gain among those who later sustained fractures.

There is also considerable evidence that, as for other age-related diseases such as coronary artery disease, hypertension, and type 2 diabetes (4), intrauterine programming contributes to the risk of osteoporosis later in life. For example, using detailed birth records from Hertfordshire, Dennison and colleagues (5) demonstrated that birth weight was significantly associated with bone mineral content (BMC) at the spine and hip in both women and men; relationships with bone mineral density (BMD) were weaker and significant at the hip in men only.

During childhood, skeletal mass increases steadily through a combination of linear growth and changes in bone density and dimensions. However, it is during pubertal growth that there is a marked acceleration in bone mass acquisition, with $25-50 \%$ of the peak bone mass of adulthood accumulated during the pubertal growth spurt $(6,7)$. This is illustrated in Figure 2, which shows the dramatic increase in the rate of bone mineral accrual in both sexes during the years of most rapid longitudinal growth. Interestingly, the pubertal growth spurt is also associated with a marked increase in the incidence of fractures during childhood, most notably fractures of the distal forearm (8-10); this is associated with a transient thinning of the cortex at the distal radius along with an increase in cortical porosity (11). Of some concern are findings from Rochester, Minnesota showing that forearm fractures have increased by $32 \%$ in boys and $56 \%$ in girls over the past 30 years (12), raising the possibility that the acquisition of bone mass (and thus bone strength) during adolescence is being impaired. While there is evidence demonstrating that adolescents who fracture have lower bone mass at various skeletal sites as compared to control subjects (13-15), the specific risk factors for these fractures (e.g., obesity), whether these deficits persist into adult 
life, and whether individuals who sustained fractures during childhood have an increased risk of osteoporotic fractures later in life remains to be clearly defined.

\section{Patterns of bone loss in women and men}

As discussed in detail in Chapter 1, DXA is a very useful clinical tool. However, it does have significant limitations, particularly in the research setting. Thus, BMD by DXA is more appropriately termed "areal" BMD (aBMD), since the bone mineral content of the bone is divided not by the true volume of the bone, but rather by the projected area (hence the units for DXA "BMD" measures of $\mathrm{g} / \mathrm{cm}^{2}$, rather than $\mathrm{g} / \mathrm{cm}^{3}$ ). Since with increasing bone size, bone mineral content increases as a cubic function, whereas the projected area increases as a squared function, a bigger bone with an identical true, volumetric BMD (vBMD) to that of a smaller bone will, by virtue of this artifact of DXA, have a higher aBMD. Moreover, DXA cannot separate the more metabolically active, trabecular bone from the more structurally important cortical bone. To circumvent these problems, recent studies have used quantitative computed tomography (QCT), along with newer image analysis tools, to assess age- and sex-specific changes in vBMD, bone size, geometry and structure at various skeletal sites. Thus, Riggs and colleagues (16) used central (at the lumbar spine and femoral neck) and peripheral (at the distal radius and tibia) QCT in an age- and sex-stratified population sample of 373 women and 323 men (age, 20-97 years) and found that in young adulthood, men had 35-42\% larger bone areas than women, consistent with their larger body size. Interestingly, bone area increased in both sexes over life (albeit assessed cross-sectionally) by $\sim 15 \%$, consistent with ongoing apposition of periosteal bone during adult life. Somewhat surprisingly, decreases in trabecular vBMD began before midlife and continued throughout life in both sexes (Figure 3A), whereas cortical vBMD decreases began in midlife (Figure 3B). Average decreases in trabecular vBMD between the ages of 20 and 90 years were greater in women $(-55 \%)$ than in men $(-46 \%)$ at the central sites, but were similar $(-24 \%$ and $-26 \%)$ at peripheral sites. With aging, cortical area decreased slightly, and the cortex was displaced outwardly by periosteal and endocortical bone remodeling. Cortical vBMD decreased over life more in women $(\sim 25 \%)$ than in men $(\sim 18 \%)$, consistent with menopausal-induced increases in bone turnover and bone porosity. These cross-sectional changes were subsequently confirmed by longitudinal data, which provided essentially identical results, including the documentation of substantial trabecular bone loss at multiple sites beginning in the third decade, well before the menopause in women or the onset of significant sex steroid deficiency in men (17). Collectively, these findings indicate that agerelated changes in bone are complex. Some are beneficial to bone strength, such as periosteal apposition with outward cortical displacement. However, others are deleterious, such as increased endocortical resorption, increased cortical porosity, and large decreases in trabecular and cortical vBMD.

The recent application of high resolution peripheral QCT (HRpQCT) at the distal radius and tibia has also provided important new information on changes in trabecular and cortical microstructure with aging. This technology uses a voxel size of $89 \mu \mathrm{m}$ to essentially obtain an "in vivo" bone biopsy at these sites, although a limitation of this approach is that central sites such as the spine and hip cannot be scanned due to the radiation doses needed for such high resolutions. Importantly, in cadaveric specimens, the bone microstructure variables 
assessed using this approach correlate extremely well $(\mathrm{R}>0.95)$ with even higher resolution $\mu \mathrm{CT}$, which is generally considered the "gold standard" technique (18). Using HRpQCT at the wrist in a population-based cross-sectional study involving 324 women and 278 men age 21-97 years (19), we found that relative to young women (age 20-29 years), young men had greater trabecular bone volume/tissue volume (BV/TV; by 26\%) and trabecular thickness (TbTh, by 28\%) but similar values for trabecular number ( $\mathrm{TbN}$ ) and trabecular separation (TbSp). Between ages 20 and 90 years, cross-sectional decreases in BV/TV were similar in women $(-27 \%)$ and in men $(-26 \%)$, but whereas women had significant decreases in $\mathrm{TbN}$ $(-13 \%)$ and increases in $\mathrm{TbSp}(+24 \%)$, these parameters had little net change over life in men. However, TbTh decreased to a greater extent in men $(-24 \%)$ than in women $(-18 \%)$. These population-based structural data thus demonstrated that while decreases in trabecular $\mathrm{BV} / \mathrm{TV}$ with age are similar in men and women, the structural basis for this decrease is quite different between the sexes. Over life, women undergo loss of trabeculae with an increase in TbSp, whereas men being young adult life with thicker trabeculae and primarily sustain trabecular thinning, with no net change in TbN or TbSp. This has important biomechanical consequences, since decreases in $\mathrm{TbN}$ have been shown to have a much greater impact on bone strength as compared with decreases in TbTh (20). These findings may help explain the lower life-long risk of fractures in men, and specifically their virtual immunity to agerelated increases in distal forearm fractures.

To summarize, much of adult bone mass is achieved during childhood and particularly during adolescent growth. During this period, there is also a reproducible (across multiple populations) increase in fractures, predominantly of the distal radius, which appears to be due to transient decreases in cortical thickness and increase in cortical porosity (11), at least at this site. Recent data using QCT have also demonstrated that trabecular bone mass seems to "peak" in early adult life (although the timing of acquisition of peak bone mass may be different at different sites), with decreases in trabecular bone evident in both sexes as early as the third decade, although these decreases clearly accelerate around the time of the menopause in women. By contrast, cortical bone remains stable in both sexes until the menopause in women and somewhat later in life in men, with subsequent decreases in cortical bone present in both sexes. At a microstructural level, women lose bone primarily via decreases in trabecular numbers (i.e., complete loss of trabeculae), whereas men principally undergo trabecular thinning; the former is structurally much more destabilizing, and may account, at least, in part, for the higher lifetime risk of fractures in women as compared to men.

\section{Role of the menopause in women and sex steroid deficiency in men Role of menopause and estrogen deficiency in women}

Albright and colleagues (21) initially postulated almost 70 years ago that osteoporosis in aging women was related to the postmenopausal state and estrogen deficiency and showed that estrogen treatment improved calcium balance in postmenopausal women. Using photon absorptiometry at the metacarpals, Lindsay et al. subsequently validated the original Albright hypothesis by demonstrating that the accelerated bone loss induced by ovariectomy could be prevented by estrogen therapy (22). Subsequent work has now clearly 
demonstrated the importance of the menopause and estrogen deficiency as perhaps the major contributor to age-related bone loss in women, and this is illustrated well by the clinical example provided as Case 3 in Chapter 1 . Thus, there is an early phase of predominantly trabecular bone loss following the menopause associated with the fall in estrogen (estradiol by $\sim 90 \%$ and estrone by $\sim 75 \%$ ) (23). Serum testosterone levels also decrease following the menopause, but this decrease is more modest, since testosterone continues to be produced by the adrenal cortex as well as the interstitial cells of the ovary (24). The observed decrease in bone mass at multiple sites is associated with marked increases in biochemical markers of bone resorption, whereas markers of bone formation increase to a lessor extent (Figure 4), consistent with increased bone resorption as well as a relative deficit in bone formation in the setting of estrogen deficiency that leads to bone loss. The rapid bone loss during the early postmenopausal years produces an increased flux of calcium from bone into the extracellular pool, but hypercalcemia does not develop due to compensatory increases in urinary calcium excretion (25) and decreases in intestinal calcium absorption (26) as well as decreases in parathyroid hormone (PTH) secretion (27).

The homeostatic mechanisms limiting the early, rapid phase of bone loss following the menopause in women are still not well understood. One possibility is that once sufficient bone is lost, increased mechanical strain on cells (specifically, osteocytes embedded within bone) may trigger compensatory pathways to limit bone loss (28). Nonetheless, ongoing estrogen deficiency in women is associated with progressive loss of trabecular and cortical bone. The effects of estrogen deficiency are compounded later in life by the onset of secondary hyperparathyroidism, since aging in women (and in men, see below) is associated with a progressive increase in serum PTH levels (27). Indeed, formal studies of parathyroid secretory dynamics by sequential infusions of calcium or EDTA have shown that, compared with young adult women, elderly women have greater basal, maximal, and non-suppressible levels of PTH secretion without alterations in the set-point for PTH secretion (29). These functional properties are characteristic of parathyroid hyperplasia, and are consistent with a histological autopsy study showing a trend to parathyroid hyperplasia in elderly women and men (30).

The increase in PTH secretion with aging in women clearly contributes to the increase in bone turnover and bone loss, since McKane et al. (31) demonstrated that a chronically high calcium intake reduced the elevated levels of serum PTH and bone turnover markers in elderly women to within the normal range for premenopausal women. However, the level of calcium intake $(2400 \mathrm{mg} / \mathrm{d})$ in the treatment group of that study was much higher than the average calcium intake among American postmenopausal women of $700 \mathrm{mg} / \mathrm{d}$ (32).

The increase in PTH with age in women (and in men) is likely due to multiple causes. As discussed in detail in Chapter 1, vitamin D deficiency is a significant problem among the elderly and certainly plays a major role (33). It is also evident, however, that estrogen deficiency itself may contribute to age-related increases in PTH levels due to loss of the positive effects of estrogen on non-skeletal calcium homeostasis - specifically, on enhancing intestinal (26) and renal (34) calcium absorption. Thus, the chronic loss of these extraskeletal actions of estrogen results in ongoing calcium wasting and ultimately, contributes to the development of secondary hyperparathyroidism. 
While estrogen deficiency is associated with increased bone resorption and a compensatory (albeit insufficient) increase in bone formation (Figure 4), recent studies in humans have directly demonstrated the importance of estrogen not only in suppressing bone resorption, but also in maintaining bone formation. Thus, as shown in Figure 5, acute estrogen deficiency is associated, as expected, with an increase in bone resorption markers; however, in contrast to chronically estrogen deficient women who have had time to mount a compensatory increase in bone formation (35), following acute estrogen deprivation, bone formation markers decrease significantly (36). Conversely, Hannon and colleagues (37) have shown that while chronic estrogen treatment is associated with reductions in bone resorption and formation markers, early after estrogen treatment, bone resorption markers fall, whereas bone formation markers actually increase. Collectively, these data in women, which are further supported by studies in men (see below) provide convincing evidence that estrogen not only suppresses bone resorption, but is also critical for the maintenance of bone formation. Following estrogen deficiency, bone resorption increases, and due to the coupling of bone resorption and bone formation (38), bone formation also increases over time; however, due to the absence of estrogen, there is a persistent gap between bone resorption and bone formation, leading to the observed bone loss.

\section{Role of sex steroid deficiency in men}

While men do not have the equivalent of the menopause, total testosterone levels do decline with aging $(39,40)$. More importantly, a number of studies have now demonstrated that the biologically available fraction of testosterone and estrogen (i.e., the fraction not bound to sex hormone binding globulin [SHBG]) declines markedly with aging in men, due in large part to a near doubling in SHBG levels over life combined with an inadequate compensatory response by the aging hypothalamic-pituitary-testicular axis to appropriately compensate for the declining bioavailable sex steroid levels $(39,40)$. Thus, in a population-based sample of 350 men between the ages of 20 and 90 years, we found that bioavailable testosterone decreased over life by 64\%, bioavailable estrogen by $47 \%$, and SHBG rose by $124 \%$ (39). The precise cause(s) for the age-related increase in SHBG levels remains unclear at present, but may be related, at least in part, to declining IGF-I levels.

Although both serum free or bioavailable testosterone and estradiol levels decline with age in men, it had generally been believed that because testosterone is the major sex steroid in men, it was the decrease in bioavailable testosterone levels that would be associated most closely with bone loss in men. However, Slemenda and colleagues (41) found that BMD (assessed by DXA) at various sites in 93 healthy men over age 55 years correlated with serum estradiol levels (correlation coefficients, depending on the site, of +0.21 to $+0.35, \mathrm{P}=$ 0.01 to 0.05 ) and, in fact, inversely with serum testosterone levels (correlation coefficients of -0.20 to $-0.28, P=0.03$ to 0.10 ). Subsequent to this report, other similar cross-sectional studies have demonstrated significant positive associations between BMD by DXA and estrogen levels in men $(39,42-47)$, particularly circulating bioavailable estradiol levels. These cross-sectional findings have subsequently been validated by longitudinal data. Thus, we (48) studied, in a longitudinal manner, elderly (60 to 90 years) men in whom rates of change in BMD using DXA at various sites over 4 years were related to sex steroid levels. Forearm sites (distal radius and ulna) provided the clearest data, perhaps because of the 
greater precision of peripheral site measurements as compared with central sites, such as the spine or hip. BMD at the forearm sites declined by $0.49 \%$ to $0.66 \%$ per year in these men, and these decreases were associated with serum bioavailable estradiol levels more closely than with bioavailable testosterone levels. Moreover, further analysis of the data suggested that there may be a threshold bioavailable estradiol level of approximately $40 \mathrm{pmol} / \mathrm{L}$ (11 $\mathrm{pg} / \mathrm{ml}$ ), below which the rate of bone loss in these men clearly was associated with bioavailable estradiol levels. Above this level, there did not appear to be any relationship between the rate of bone loss and bioavailable estradiol levels. In these older men, the bioavailable estradiol level of $40 \mathrm{pmol} / \mathrm{L}(11 \mathrm{pg} / \mathrm{ml})$ represented the median bioavailable estradiol level in these men and corresponded to a total estradiol level of approximately 114 $\mathrm{pmol} / \mathrm{L}(31 \mathrm{pg} / \mathrm{mL})$, which is close to the middle of the reported normal range for estradiol levels in men (10 to $50 \mathrm{pg} / \mathrm{mL}$ ). Similar findings were reported by Gennari and colleagues (49) where, in a cohort of elderly Italian men, those subjects with serum free estradiol levels below the median value lost bone over 4 years at the lumbar spine and femur neck, whereas the men with free estradiol levels above the median did not lose bone. In further studies using QCT at various sites, we (50) found that in elderly men, bioavailable estradiol was the most consistent predictor of vBMD and some of the geometric variables related to bone size, and that the possible "threshold" for skeletal estrogen deficiency was most evident at cortical sites. Moreover, at least in men, serum estradiol levels measured by either a sensitive radioimmunoassay or by tandem mass spectroscopy provided virtually identical correlations with BMD (51).

While these studies helped to establish that estrogen levels are associated with skeletal maintenance in males, they could not definitively establish causal relationships. In order to address this issue, Falahati-Nini et al. (52) performed a direct interventional study to distinguish between the relative contributions of estrogen versus testosterone in regulating bone resorption and formation in normal elderly men. Endogenous estrogen and testosterone production were suppressed in 59 elderly men using a combination of a long acting GnRH agonist and an aromatase inhibitor. Physiologic estrogen and testosterone levels were maintained by simultaneously placing the men on estrogen and testosterone patches delivering doses of sex steroids that mimicked circulating estradiol and testosterone levels in this age group. After baseline measurements of bone resorption [urinary deoxypyridinoline (Dpd) and N-telopeptide of type I collagen (NTx)] and bone formation [serum osteocalcin and amino-terminal propeptide of type I collagen (PINP)] markers, the subjects were randomized to one of 4 groups: Group A $(-\mathrm{T},-\mathrm{E})$ discontinued both the testosterone and estrogen patches; Group B $(-\mathrm{T},+\mathrm{E})$ discontinued the testosterone patch but continued the estrogen patch; Group $\mathrm{C}(+\mathrm{T},-\mathrm{E})$ discontinued the estrogen patch but continued the estrogen patch; and Group D $(+\mathrm{T},+\mathrm{E})$ continued both patches. Since gonadal and aromatase blockade was continued throughout the 3 week period, separate effects of estrogen versus testosterone (in the absence of aromatisation to estrogen) on bone metabolism could be delineated.

As shown in Figure 6A, significant increases in both urinary Dpd and NTx excretion, Group $\mathrm{A}(-\mathrm{T},-\mathrm{E})$, were prevented completely by continuing testosterone and estrogen replacement [Group D $(+\mathrm{T},+\mathrm{E})$ ]. Estrogen alone (Group B) was almost completely able to prevent the increase in bone resorption, whereas testosterone alone (Group C) was much less effective. 
Using a 2-factor ANOVA model, the effects of estrogen on urinary Dpd and NTx excretion were highly significant $(\mathrm{P}=0.005$ and 0.0002 , respectively). Estrogen accounted for $70 \%$ or more of the total effect of sex steroids on bone resorption in these older men, while testosterone could account for no more than $30 \%$ of the effect. Using a somewhat different design, Leder et al. (53) confirmed an independent effect of testosterone on bone resorption, although the data in the aggregate clearly favor a more prominent effect of estrogen on the control of bone resorption in men.

Figure 6B shows the corresponding changes in the bone formation markers, serum osteocalcin and PINP. The reductions in both osteocalcin and PINP levels with the induction of sex steroid deficiency (Group A) were prevented with continued estrogen and testosterone replacement (Group D). Interestingly, serum osteocalcin, which is a marker of function of the mature osteoblast and osteocyte (54), was maintained by either estrogen or testosterone (ANOVA P values of 0.002 and 0.013 , respectively). By contrast, serum PINP, which represents type I collagen synthesis throughout the various stages of osteoblast differentiation (55), was maintained by estrogen (ANOVA P value 0.0001 ), but not testosterone.

Collectively, these findings provided conclusive proof of an important (and indeed, dominant) role for estrogen in bone metabolism in the mature skeleton of adult men. Moreover, several recent studies have now extended these findings and evaluated the relative role of estrogens and androgens on fracture risk in men. Thus, Amin and colleagues (56) related sex steroid levels in aging men from the Framingham Study to the risk for hip fractures. In this study, 793 men (mean age, 71 years) evaluated between 1981 and 1983 were followed until the end of 1999 . The men were stratified into 3 groups, according to serum estradiol and testosterone levels. Based on 39 men who sustained a hip fracture during follow up, incidence rates for hip fracture (per 1000 person-years) were 11.0, 3.4, and 3.9 for the low $(2.0-18.1 \mathrm{pg} / \mathrm{ml})$, middle $(18.2-34.2 \mathrm{pg} / \mathrm{ml})$, and high $(\geq 34.3 \mathrm{pg} / \mathrm{ml})$ estradiol groups, respectively. Following adjustment for age, body mass index, height, and smoking status, the adjusted hazard ratios (HRs) for men in the low and middle estradiol groups, relative to the high estradiol group, were 3.1 (95\% CI, 1.4-6.9) and 0.9 (95\% CI, 0.4-2.0), respectively, consistent with the presence of a threshold estradiol level around 18 $\mathrm{pg} / \mathrm{ml}$ below which fracture risk increased in the men. By contrast, in similar adjusted analyses evaluating men by their testosterone levels, the investigators found no significant increased risk for hip fracture associated with low testosterone levels.

Somewhat contrasting findings were reported from men in the Dubbo cohort by Meier and colleagues (57) who found that while serum testosterone was not related to lumbar spine or femoral neck BMD in 609 men over the age of 60 years, lower testosterone levels were stronger predictors of low trauma fractures than were estradiol levels, despite the fact that estradiol was significantly associated with spine and hip BMD in these men. These findings suggested that the effect of testosterone on fracture risk in elderly men may be mediated via non-skeletal factors, such as muscle strength and/or fall risk.

The most definitive data addressing this issue have come from the MrOS cohort. In the first of these studies, Mellström et al. (58) analyzed sex steroids using gas chromatography-mass 
spectroscopy in 2639 elderly men (mean age, 75 years) from the Swedish arm of MrOS and evaluated fractures over a mean follow up period of 3.3 years. In multivariable proportional hazards regression models, free estradiol and sex hormone binding globulin (SHBG), but not free testosterone, were independently associated with fracture risk. In further subanalyses, free estradiol was inversely associated with clinical vertebral fractures (HR per SD decrease, 1.57; 95\% CI, 1.36-1.80), nonvertebral osteoporotic fractures (HR per SD decrease, 1.42; 95\% CI, 1.23-1.65), and hip fractures (HR per SD decrease, 1.44; 95\% CI, 1.18-1.76). Furthermore, consistent again with a threshold effect, the inverse relation between serum estradiol and fracture risk was non-linear. Specifically, the yearly incidence of fractures was inversely associated with serum estradiol levels at estradiol levels less than $16 \mathrm{pg} / \mathrm{ml}$; above this level, there was no relationship between fracture incidence and estradiol levels.

LeBlanc et al. (59) have subsequently expanded these findings to include the larger US cohort of MrOS involving 5995 men age 65 years and older, of which they randomly selected a subcohort of 1436 white men and all 446 minority participants, plus all subjects with incident hip and other nonvertebral fractures. Consistent with the previous data and with the notion of a threshold, they found that men in the lowest bioavailable (non-SHBG bound) estradiol quartile $(<11.4 \mathrm{pg} / \mathrm{ml})$ or highest SHBG quartile $(>59.1 \mathrm{nM})$ had greater risk of all nonvertebral fractures; by contrast, men with the lowest bioavailable testosterone level had no increased fracture risk after adjustment for bioavailable estradiol. However, these investigators did observe an interesting interaction $(\mathrm{P}=0.03)$ between SHBG and bioavailable testosterone: men with low bioavailable testosterone and high SHBG did have an increase in fracture risk, with the highest risk of fracture occurring in men with low bioavailable estradiol, low bioavailable testosterone, and high SHBG.

Taken together, these studies using fracture as outcomes have provided further support for a key role for estradiol in determining fracture risk in aging men, as well as the presence of a threshold estradiol level (which may vary, depending on the particular assay used) below which fracture risk increases in men. Testosterone may also contribute to fracture risk, particularly in the setting of high SHBG levels. Moreover, it is probable that a significant component of the testosterone effect on risk of fracture is mediated by non-skeletal effects, such as on muscle mass, balance, or risk of falls, although further studies directly addressing this issue are needed.

\section{Additional endocrine pathways linked with bone loss}

In addition to sex steroids, a number of other endocrine pathways have recently been linked with bone loss in both experimental and clinical studies. Thus, Sun et al. (60) have suggested that the postmenopausal increase in bone resorption may not be due principally to estrogen deficiency, but rather to the concomitant increase in circulating FSH levels. This hypothesis is based on in vitro studies demonstrating that FSH increases osteoclastogenesis through activation of MEK/Erk, NF- $\mathrm{BB}$, and Akt signaling and the observation that, despite having estrogen deficiency, FSH-receptor null mice have normal bone mass (60).

Furthermore, data from the Study of Women's Health Across the Nation cohort indicate that serum FSH was the most robust predictor of bone loss through the menopausal transition (61). In contrast to these findings, studies by a different group with the identical FSH- 
receptor null mice used by Sun et al. (60) did find deficits in bone mass in these mice (62). Moreover, recent findings demonstrate that at least in men, sex steroid deficiency alone is sufficient to increase bone resorption markers, even in the setting of suppressed FSH levels (63). Thus, the precise role of increases in FSH with aging in women and in men in mediating age-related bone loss remains unclear at this time.

Recent studies also indicate that inhibins A and B, which decline following the menopause in women and with aging in men, may also regulate bone metabolism. Thus, declining inhibin levels correlate with bone turnover markers in perimenopausal women (64), and in vitro studies have found that inhibins suppress osteoblast and osteoclast development (65).

Considerable attention has also recently been focused on the possible role of serotonin in bone metabolism. In a cross-sectional analysis of MrOS data, Haney et al. (66) found that mean BMD among men who used selective serotonin reuptake inhibitors (SSRIs) $(\mathrm{n}=160)$ was 3.9\% lower at the total hip and 5.9\% lower at the lumbar spine as compared to BMD in men not on antidepressants ( $\mathrm{n}=5708, \mathrm{P}=0.002$ for total hip; $\mathrm{P}<0.001$ for spine). By contrast, other antidepressants (trazodone hydrochloride, tricyclic antidepressants) were not associated with decreased BMD. These clinical findings are of particular interest given recent provocative data by Yadav and colleagues (67) showing that duodenum-derived serotonin inhibits bone formation, unveiling perhaps an entirely novel entero-skeletal regulatory system. In women, serum serotonin levels have been found to be inversely associated with bone mass and structural parameters at various skeletal sites (68); whether similar associations are present in men and the precise role for serotonin in regulating bone turnover in humans remains an area of active investigation.

\section{Cellular and molecular mechanisms of sex steroid action on bone Effects of sex steroids on bone remodeling}

A major consequence of estrogen deficiency in women and testosterone deficiency in men (which represents combined testosterone and estrogen deficiency, due to the aromatization of testosterone to estradiol) is an increase in bone remodeling by basic multicellular units (BMUs), which are temporary anatomic structures comprising osteoclasts in the front and osteoblasts in the rear (69); as discussed below, however, this increase in bone remodeling is accompanied by a relative deficit in bone formation, leading to bone loss. In a series of studies, Jilka and colleagues (70) have demonstrated that loss of estrogen in mice is associated with marked, simultaneous increases in osteoclastic precursors [colony forming units-granulocytes/macrophages (CFU-GMs), from hematopoietic lineage cells) and early osteoblastic precursors [colony forming units-osteoblasts (CFU-OBs), from mesenchymal lineage cells] in the marrow. These increases were found even in the presence of the inhibitor of bone resorption, alendronate, demonstrating that prior bone resorption (and the subsequent release of growth factors from the bone matrix) was not required for the increase in osteoblast precursors, establishing a direct, suppressive effect of estrogen on both osteoclast and osteoblast precursors. In further studies, these investigators went on to demonstrate that the CFU-OBs were early transit-amplifying progenitors (i.e., dividing cells capable of limited self-renewal) and that estradiol attenuated their self-renewal by $\sim 50 \%$ (71). Since both osteoblasts and the stromal/osteoblastic cells that are required for osteoclast 
development (see below) are derived from CFU-OBs, suppression of the self-renewal of this common progenitor may represent a key mechanism of the anti-remodeling effects of estrogens. Whether androgens (in the absence of aromatization to estrogen) have similar, suppressive effects on CFU-OBs and/or CFU-GMs has not been directly examined.

\section{Effects of sex steroids on bone resorption}

In addition to reducing the outflow of osteoblast and osteoclast precursors from hematopoietic and mesenchymal lineage cells, respectively, estrogen, as well as androgens, have clear effects on osteoclast development, activity, and apoptosis. Figure 7 provides a summary of the cellular and molecular factors involved in osteoclast differentiation and function. The key, essential molecule for osteoclast development is receptor activator of NF$\kappa \mathrm{B}$ ligand (RANKL) (72), which is expressed on the surface of bone marrow stromal/ osteoblast precursor cells, T-cells, as well as B-cells (73). RANKL binds its cognate receptor, RANK, on osteoclast lineage cells (74), and is neutralized by the soluble, decoy receptor, osteoprotegerin (OPG), which is also produced by osteoblastic lineage cells (75). Combined in vitro and in vivo studies have now demonstrated that estrogen suppresses RANKL production by osteoblastic, T- and B-cells (73) and also increases OPG production $(76,77)$. Moreover, at least in vitro, androgens also suppress RANKL production by primary murine osteoblastic cells (78).

In addition to the effects of estrogen on RANKL and OPG expression, estrogen also regulates the production of additional cytokines in osteoblasts or bone marrow mononuclear cells, thus modulating osteoclastic activity in a paracrine fashion (79). There is now an increasing body of evidence that bone-resorbing cytokines, such as interleukin (IL)-1, IL-6, tumor necrosis factor-a (TNF-a), macrophage-colony stimulating factor (M-CSF), and prostaglandins may be potential candidates for mediating the bone loss following estrogen deficiency, at least in mouse models, although it remains unclear whether the effects of these cytokines are mediated ultimately by effects on RANKL and/or OPG production or are independent of these molecules. Both IL-1 and M-CSF production are increased in estrogen deficient model systems $(80,81)$ which can be inhibited using specific antagonists (82-84). Additionally, the bone resorptive effects of TNF- $a$ are well documented and can be reversed using a soluble type I TNF receptor (85). To evaluate the possible role of IL-1 and TNF-a in mediating increases in bone resorption following estrogen deficiency in humans, Charatcharoenwitthaya et al. (36) administered anakinra or etanercept, specific blockers of IL-1 and TNF-a, respectively, to postmenopausal women following acute estrogen withdrawal. Each of the two blockers reduced the rise in bone resorption markers to about one half of that in controls, consistent with an important role for these immune cytokines in mediating the effect of estrogen deficiency on bone not only in mice, but also in humans.

Numerous other studies indicate that IL-6 also plays a key role in mediating bone loss following estrogen or androgen deficiency $(86,87)$. However, it is likely that, in vivo, multiple cytokines act cooperatively in inducing bone resorption following sex steroid deficiency, and that a single cytokine may only partially account for the effects of sex steroid deficiency on the skeleton. Finally, in addition to suppressing the production of pro- 
resorptive cytokines, estrogen also stimulates the production of TGF- $\beta$ by osteoblastic cells (88); TGF- $\beta$, in turn, has been shown to induce apoptosis of osteoclasts (89).

Sex steroids also have direct effects on osteoclast lineage cells. Thus, both estrogen and androgens induce apoptosis of these cells $(89,90)$, and both sex steroids suppress RANKLinduced osteoclast differentiation by blocking RANKL/M-CSF-induced activator protein-1dependent transcription through a reduction of c-jun activity. The latter is due both to reduced c-jun expression and decreased phosphorylation (91-93). Moreover, estrogen and androgens have also been shown to inhibit the activity of mature osteoclasts through direct, receptor-mediated mechanisms $(94,95)$. The most conclusive evidence for estrogen's effect on osteoclasts has come from Nakamura and colleagues (96) who showed that osteoclastspecific deletion of the estrogen receptor a in mice resulted in increased bone resorption and reduced bone mass.

As is evident, estrogen (and perhaps to a lesser extent, androgens) have pleiotropic effects on virtually all aspects of osteoclast development, activity, and lifespan. It is not surprising, therefore, that the cardinal skeletal consequence of estrogen deficiency in humans and in rodents is a marked stimulation of bone resorption.

\section{Effects of sex steroids on bone formation}

The increase in bone remodeling and in bone resorption in the setting of sex steroid deficiency is accompanied by a coupled increase in bone formation at the tissue level. However, at each BMU, there remains a gap between bone resorption and formation, with formation unable to keep up with resorption, resulting in a net loss of bone. By inference, therefore, sex steroid deficiency is associated with a defect in bone formation; further evidence for this is provided by the results of the physiological studies shown in Figures 5 and 6, which demonstrate the importance of both estrogen and testosterone in maintaining bone formation in humans. Of interest, recent work by Chang and colleagues (97) has demonstrated that estrogen deficiency in mice is associated with a marked increase in NF$\kappa \mathrm{B}$ activity in osteoblastic cells. Moreover, these investigators found that inhibiting NF- $\kappa \mathrm{B}$ action attenuated bone loss following ovariectomy by reducing the gap between bone resorption and bone formation. Thus, NF- $\mathrm{kB}$ may be a key mediator of the relative deficit in bone formation that is present in vivo following estrogen deficiency.

At the cellular level, there is now considerable evidence that both estrogen and testosterone also prolong the lifespan of the osteoblast by inhibiting osteoblast apoptosis (98). This, in turn, increases the functional capacity of each osteoblast. Conversely, sex steroid deficiency is associated with accelerated osteoblast apoptosis, likely contributing to the gap between bone formation and resorption noted previously. Sex steroid effects on osteoblast apoptosis appear to be mediated by activation of the Src/Shc/ERK signaling pathway (98) and downregulation of JNK, leading to alterations in the activity of key transcription factors, including Elk-1, CCAAT enhancer binding protein- $\beta$ (C/EBP $\beta)$, cyclic adenosine monophosphate-response element binding protein (CREB), and c-Jun/cFos (99).

In vitro, estrogen effects on osteoblast proliferation and differentiation markers have been variable, depending on the model system used $(100,101)$. It also appears that the effects of 
estrogen on progenitor and osteoblastic cells may be stage-specific. Thus, consistent with the overall effects of estrogen on reducing bone remodeling, estrogen does reduce the self renewal of early mesenchymal progenitors (71). Perhaps the most consistent effects of estrogen are on inducing commitment of precursor cells to the osteoblast at the expense of the adipocyte lineage $(102,103)$. Thus, using both a mouse osteoprogenitor cell line (KS483) and primary mouse bone marrow cells, Dang et al. (103) found that estradiol stimulated the differentiation of these cells into osteoblasts and concurrently inhibited adipocyte formation. Estradiol also increased alkaline phosphatase activity and mineralized nodule formation.

Recent evidence also suggests that, in addition to the osteoblast, the osteocyte may also be a target for estrogen action. Estrogen withdrawal associated with GnRH therapy has, for example, been shown to induce apoptosis of osteocytes in iliac bone (104). Furthermore, estrogen treatment inhibits osteocyte apoptosis induced by pro-apoptotic stimuli (98). Since osteocytes may be involved in mechanosensing and transducing loading responses (105), these effects of estrogen deficiency could potentially impair the skeletal response to loading.

As in the case of estrogen, in vitro studies of androgen effects on osteoblast proliferation and differentiation have yielded inconsistent results. Androgens have been shown to have mitogenic effects on normal and transformed osteoblast-like cells in most $(106,107)$, but not all systems $(108,109)$. With respect to osteoblast differentiation, androgens have been shown to increase alkaline phosphatase activity in primary cultures of osteoblast-like cells and the percentage of alkaline phosphatase-positive cells, suggesting a shift towards a more differentiated phenotype $(107,110,111)$. On the other hand, studies using a fetal human osteoblast cell line stably transfected with the androgen receptor have found a decrease in alkaline phosphatase activity in these cells following dihydrotestosterone exposure (109). Androgen effects on type I collagen synthesis have been variable, with some studies showing a stimulatory effect $(106,108,110)$, and others finding no effect (112), or even a decrease (109) in collagen synthesis. Finally, studies using primary osteoblast cultures have suggested that some of the effects of androgens in these cells may be mediated, at least in part, by increased TGF- $\beta$ production, or by alterations in the insulin-like growth factor/ insulin-like growth factor binding protein system $(113,114)$.

\section{Cellular mechanisms of aging in bone}

In addition to the key effects of sex steroid deficiency in women and in men described above, it is clear that there are intrinsic changes in the skeletal metabolism that contribute to age-related bone loss. Some of these, discussed below, impact on a major signaling pathway, Wnt, involved in bone formation and resorption. Initial observations regarding the role of this pathway in bone metabolism came from loss or gain of function mutations of the lowdensity lipoprotein receptor-related protein 5 or 6 (LRP-5 or LRP-6), which are co-receptors for secreted Wnt proteins (115). Wnt signaling activates beta-catenin, which then regulates the commitment of multipotent mesenchymal progenitors to the osteoblast lineage, prevents osteoblast apoptosis, and also increases OPG production, leading to both a stimulation of bone formation and an inhibition of bone resorption (115). In a series of studies, Almeida and colleagues (116) have shown that in mice, aging is associated with an increase in 
markers of oxidative stress in osteoblastic cells, which results in an increase in Forkhead box $\mathrm{O}$ (FoxO) transcription factors. While FoxO induction is critical in the defense against oxidative stress, these investigators also found that by competing for cellular beta-catenin, the increase in FoxO expression leads to a reduction in Wnt signaling in bone. Given the key role for Wnts in bone metabolism (115), these findings suggest that oxidative stress, which increases with aging but is accentuated by sex steroid deficiency (116), may be an important factor leading to impaired bone formation with aging.

There has also been considerable interest recently in the role of the nutrient-sensing NADdependent protein deacetylases, sirtuins, in aging phenotypes in a number of tissues (117). Thus, it is of interest that Edwards et al. (118) have found that mice with global deletion of sirtuin 1 (SIRT-1) have a decrease in bone mass associated with decreased bone formation and increased bone resorption. In further studies, these investigators showed that osteoblastspecific deletion of SIRT-1 results in low bone formation, whereas deletion of SIRT-1 in osteoclast precursor cells leads to an increase in bone resorption (119). These findings therefore demonstrate that age-related changes in SIRT-1 activity may also contribute to age-related bone loss, at least in rodent models. Additional support for this hypothesis comes from data showing that the SIRT-1 agonist, resveratrol, results in preservation of BMD in aging mice (120) and can prevent ovariectomy-induced bone loss (121).

Thus, while much more work is needed to define intrinsic, cell autonomous changes in bone cells with aging, it is clear from these studies that while sex steroid deficiency plays a major role in age-related bone loss, there is are underlying processes of skeletal aging that likely occur independent of the effects of sex steroids. However, sex steroid deficiency may accentuate some of these intrinsic changes of aging (for example, oxidative stress). Additional studies examining other aspects of organismal aging, such as the accumulation of senescent cells in various tissues, which produce a number of pro-inflammatory cytokines (122), and the effects of these cells and their secreted products on skeletal aging need to be done.

\section{Secondary osteoporosis}

As indicated in Figure 1 and illustrated by Case 2 in Chapter 1, a number of causes of bone loss are often superimposed on the effects of sex steroid deficiency and aging and contribute to fracture risk in specific individuals. As an estimate, these conditions may contribute to fracture risk in about $40 \%$ of aging men and $20 \%$ of women (123). These include various genetic disorders, endocrine diseases, use of certain drugs such as corticosteroids, diseases such as malabsorption, anorexia nervosa, and renal hypercalciuria, and behavioral factors such as smoking, alcohol abuse, and physical inactivity. Table 1 provides a summary of most of the known secondary causes of osteoporosis; a detailed description of these is beyond the scope of the present discussion, but this has been recently reviewed (see Lowe et al. (124)). 


\section{Summary and conclusions}

There have been considerable advances in our understanding of the pathogenesis of bone loss and osteoporosis in women and in men. As discussed in Chapter 4, many of these advances are being translated into novel therapeutic approaches. Thus, a better understanding of estrogen and androgen signaling in bone has set the stage for the development of selective estrogen and androgen receptor modulators to prevent and treat osteoporosis. Identification of the role of increased RANKL production in the setting of estrogen deficiency has provided a basis for blocking this pathway as a new approach to potently inhibiting bone resorption. The key role of Wnt signaling in bone metabolism and possibly in age-related bone loss has led to the development of specific activators of this pathway in treating osteoporosis. The role of SIRT-1 in skeletal aging may also lead to new compounds regulating this pathway as a means to both stimulate bone formation and inhibit bone resorption. As these examples illustrate, the collective basic and translational effort to understand the pathogenesis of osteoporosis has formed a firm foundation on which to build various therapeutic strategies to prevent and cure this important public health problem.

\section{Acknowledgments}

Supported by NIH Grants AG004875, AG028936, and AR027065.

The authors would like to thank James Peterson for help with the figures and Amanda Oelkers for secretarial assistance.

\section{REFERENCES}

1. Riggs BL, Khosla S, Melton LJ. Sex steroids and the construction and conservation of the adult skeleton. Endocr Rev. 2002; 23:279-302. [PubMed: 12050121]

2. Khosla S, Melton LJ, Riggs BL. Estrogen and the male skeleton. J Clin Endocrinol Metab. 2002; 87:1443-1450. [PubMed: 11932262]

3. Cooper C, Eriksson JG, Forsen T, Osmond C, Tuomilehto J, Barker DJP. Maternal height, childhood growth and risk of hip fracture in later life: a longitudinal study. Osteoporos Int. 2001; 12:623-629. [PubMed: 11580075]

4. Barker DJ. The Wellcome Foundation Lecture, 1994. The fetal origins of adult disease. Proc Biol Sci. 1995; 262:37-43. [PubMed: 7479990]

5. Dennison EM, Syddall HE, Sayer AA, Gilbody HJ, Cooper C. Birth weight and weight at 1 year are independent determinants of bone mass in the seventh decade: the Hertfordshire cohort study. Pediatr Res. 2005; 57:582-586. [PubMed: 15695596]

6. Bailey DA, McKay HA, Mirwald RL, Crocker PRE, Faulkner RA. A six-year longitudinal study of the relationship of physical activity to bone mineral accrual in growing children: the university of saskatchewan bone mineral accrual study. J Bone Miner Res. 1999; 14:1672-1679. [PubMed: 10491214]

7. Bailey DA, Martin AD, McKay HA, Whiting S, Mirwald R. Calcium accretion in girls and boys during puberty: a longitudinal analysis. J Bone Miner Res. 2000; 15:2245-2250. [PubMed: 11092406]

8. Landin LA. Fracture patterns in children. Analysis of 8,682 fractures with special reference to incidence, etiology and secular changes in a Swedish urban population 1950-1979. Acta Orthop Scand Suppl. 1983; 202:1-109. [PubMed: 6574687]

9. Kramhoft M, Bodtker S. Epidemiology of distal forearm fractures in Danish children. Acta Orthop Scand. 1988; 59:557-559. [PubMed: 3188862] 
10. Bailey DA, Wedge JH, McCulloch RG, Martin AD, Bernhardson SC. Epidemiology of fractures of the distal end of the radius in children as associated with growth. J Bone Joint Surg. 1989; 71-A: 1225-1231. [PubMed: 2777851]

11. Kirmani S, Christen D, van Lenthe GH, Fischer PR, Bouxsein ML, McCready LK, Melton LJ, Riggs BL, Amin S, Muller R, Khosla S. Bone structure at the distal radius during adolescent growth. J Bone Miner Res. 2009; 24:1033-1042. [PubMed: 19113916]

12. Khosla S, Melton LJ III, Dekutoski MB, Achenbach SJ, Oberg AL, Riggs BL. Incidence of childhood distal forearm fractures over 30 years: A population-based study. JAMA. 2003; 290:1479-1485. [PubMed: 13129988]

13. Goulding A, Cannan R, Williams SM, Gold EJ, Taylor RW, Lewis-Barned NJ. Bone mineral density in girls with forearm fractures. J Bone Miner Res. 1998; 13:143-148. [PubMed: 9443800]

14. Goulding A, Jones L, Taylor RW, Manning PJ, Williams SM. More broken bones: a 4-year double cohort study of young girls with and without distal forearm fractures. J Bone Miner Res. 2000; 15:2011-2018. [PubMed: 11028455]

15. Ma D, Jones G. The association between bone mineral density, metacarpal morphometry, and upper limb fractures in children: a population-based case-control study. J Clin Endocrinol Metab. 2003; 88:1486-1491. [PubMed: 12679427]

16. Riggs BL, Melton LJ III, Robb RA, Camp JJ, Atkinson EJ, Peterson JM, Rouleau PA, McCollough $\mathrm{CH}$, Bouxsein ML, Khosla S. Population-based study of age and sex differences in bone volumetric density, size, geometry, and structure at different skeletal sites. J Bone Miner Res. 2004; 19:1945-1954. [PubMed: 15537436]

17. Riggs BL, Melton LJ, Robb RA, Camp JJ, Atkinson EJ, McDaniel L, Amin S, Rouleau PA, Khosla S. A population-based assessment of rates of bone loss at multiple skeletal sites: evidence for substantial trabecular bone loss in young adult women and men. J Bone Miner Res. 2008; 23:205-214. [PubMed: 17937534]

18. Laib A, Ruegsegger P. Calibration of trabecular bone structure measurements of in vivo threedimensional peripheral quantitative computed tomography with 28-microm-resolution microcomputed tomography. Bone. 1999; 24:35-39. [PubMed: 9916782]

19. Khosla S, Riggs BL, Atkinson EJ, Oberg AL, McDaniel LJ, Holets M, Peterson JM, Melton LJ III. Effects of sex and age on bone microstructure at the ultradistal radius: a population-based noninvasive in vivo assessment. J Bone Miner Res. 2006; 21:124-131. [PubMed: 16355281]

20. Silva MJ, Gibson LJ. Modeling the mechanical behavior of vertebral trabecular bone: effects of age-related changes in microstructure. Bone. 1997; 21:191-199. [PubMed: 9267695]

21. Albright F, Smith PH, Richardson AM. Postmenopausal osteoporosis. JAMA. 1941; 116:24652474.

22. Lindsay R, Aitken JM, Anderson JB, Hart DM, MacDonald EB, Clarke AC. Long-term prevention of postmenopausal osteoporosis by oestrogen: evidence for an increased bone mass after delayed onset of oestrogen treatment. Lancet. 1976; 1:1038-1041. [PubMed: 57448]

23. Khosla SK, Atkinson EJ, Melton LJ III, Riggs BL. Effects of age and estrogen status on serum parathyroid hormone levels and biochemical markers of bone turnover in women: a populationbased study. J Clin Endocrinol Metab. 1997; 82:1522-1527. [PubMed: 9141544]

24. Horton R, Romanoff E, Walker J. Androstenedione and testosterone in ovarian venous and peripheral plasma during ovariectomy for breast cancer. J Clin Endocrinol Metab. 1966; 26:12671269. [PubMed: 5924286]

25. Young MM, Nordin BEC. Effects of natural and artificial menopause on plasma and urinary calcium and phosphorus. Lancet. 1967; 2:118-120.

26. Gennari C, Agnusdei D, Nardi P, Civitelli R. Estrogen preserves a normal intestinal responsiveness to 1,25-dihydroxyvitamin D3 in oophorectomized women. J Clin Endocrinol Metab. 1990; 71:1288-1293. [PubMed: 2229286]

27. Riggs BL, Khosla S, Melton LJ III. A unitary model for involutional osteoporosis: Estrogen deficiency causes both type I and type II osteoporosis in postmenopausal women and contributes to bone loss in aging men. J Bone Miner Res. 1998; 13:763-773. [PubMed: 9610739]

28. Frost HM. Perspective: on the estrogen-bone relationship and postmenopausal bone loss. J Bone Miner Res. 1999; 14:1473-1477. [PubMed: 10469274] 
29. Ledger GA, Burritt MF, Kao PC, O'Fallon WM, Riggs BL, Khosla S. Abnormalities of parathyroid hormone secretion in elderly women that are reversible by short term therapy with 1,25 dihydroxyvitamin D3. J Clin Endocrinol Metab. 1994; 79:211-216. [PubMed: 8027229]

30. Akerstrom G, Rudberg C, Grimelius L, Bergstrom R, Johansson H, Ljunghall S, Rastad J. Histologic parathyroid abnormalities in an autopsy series. Hum Pathol. 1986; 17:520-527. [PubMed: 3699813]

31. McKane WR, Khosla S, Egan KS, Robins SP, Burritt MF, Riggs BL. Role of calcium intake in modulating age-related increases in parathyroid function and bone resorption. J Clin Endocrinol Metab. 1996; 81:1699-1703. [PubMed: 8626819]

32. Looker AC, Harris TB, Madans JH, Sempos CT. Dietary calcium and hip fracture risk: The NHANES I epidemiologic follow-up study. Osteoporos Int. 1993; 3:177-184. [PubMed: 8338972]

33. Holick MF. Vitamin D deficiency. N Engl J Med. 2007; 357:266-281. [PubMed: 17634462]

34. McKane WR, Khosla S, Burritt MF, Kao PC, Wilson DM, Ory SJ, Riggs BL. Mechanism of renal calcium conservation with estrogen replacement therapy in women in early postmenopause - a clinical research center study. J Clin Endocrinol Metab. 1995; 80:3458-3464. [PubMed: 8530583]

35. Garnero P, Sornay-Rendu E, Chapuy M, Delmas PD. Increased bone turnover in late postmenopausal women is a major determinant of osteoporosis. J Bone Miner Res. 1996; 11:337349. [PubMed: 8852944]

36. Charatcharoenwitthaya N, Khosla S, Atkinson EJ, McCready LK, Riggs BL. Effect of blockade of TNF-a and interleukin-1 action on bone resorption in early postmenopausal women. J Bone Miner Res. 2007; 22:724-729. [PubMed: 17295604]

37. Hannon R, Blumsohn A, Naylor K, Eastell R. Response of biochemical markers of bone turnover to hormone replacement therapy: impact of biological variability. J Bone Miner Res. 1998; 13:1124-1133. [PubMed: 9661076]

38. Martin TJ, Sims NA. Osteoclast-derived activity in the coupling of bone formation to resorption. Trends Mol Med. 2005; 11:76-81. [PubMed: 15694870]

39. Khosla S, Melton LJ III, Atkinson EJ, O'Fallon WM, Klee GG, Riggs BL. Relationship of serum sex steroid levels and bone turnover markers with bone mineral density in men and women: A key role for bioavailable estrogen. J Clin Endocrinol Metab. 1998; 83:2266-2274. [PubMed: 9661593]

40. Orwoll E, Lambert LC, Marshall LM, Phipps K, Blank JB, Barret-Conner E, Cauley J, Ensrud K, Cummings S. Testosterone and estradiol among older men. J Clin Endocrinol Metab. 2006; 91:1336-1344. [PubMed: 16368750]

41. Slemenda CW, Longcope C, Zhou L, Hui SL, Peacock M, Johnston C. Sex steroids and bone mass in older men: positive associations with serum estrogens and negative associations with androgens. J Clin Invest. 1997; 100:1755-1759. [PubMed: 9312174]

42. Greendale GA, Edelstein S, Barrett-Connor E. Endogenous sex steroids and bone mineral density in older women and men: the Rancho Bernardo study. J Bone Miner Res. 1997; 12:1833-1843. [PubMed: 9383688]

43. Center JR, Nguyen TV, Sambrook PN, Eisman JA. Hormonal and biochemica parameters in the determination of osteoporosis in elderly men. J Clin Endocrinol Metab. 1999; 84:3626-3635. [PubMed: 10523006]

44. Ongphiphadhanakul B, Rajatanavin R, Chanprasertyothin S, Piaseau N, Chailurkit L. Serum oestradiol and oestrogen-receptor gene polymorphism are associated with bone mineral density independently of serum testosterone in normal males. Clin Endocrinol. 1998; 49:803-809.

45. van den Beld AW, de Jong FH, Grobbee DE, Pols HAP, Lamberts SWJ. Measures of bioavailable serum testosterone and estradiol and their relationships with muscle strength, bone density, and body composition in elderly men. J Clin Endocrinol Metab. 2000; 85:3276-3282. [PubMed: 10999822]

46. Amin S, Zhang Y, Sawin CT, Evans SR, Hannan MT, Kiel DP, Wilson PWF, Felson DT. Association of hypogonadism and estradiol levels with bone mineral density in elderly men from the Framingham study. Ann Intern Med. 2000; 133:951-963. [PubMed: 11119396]

47. Szulc P, Munoz F, Claustrat B, Garnero P, Marchand F. Bioavailable estradiol may be an important determinant of osteoporosis in men: the MINOS study. J Clin Endocrinol Metab. 2001; 86:192-199. [PubMed: 11232000] 
48. Khosla S, Melton LJ, Atkinson EJ, O'Fallon WM. Relationship of serum sex steroid levels to longitudinal changes in bone density in young versus elderly men. J Clin Endocrinol Metab. 2001; 86:3555-3561. [PubMed: 11502778]

49. Gennari L, Merlotti D, Martini G, Gonnelli S, Franci B, Campagna S, Lucani B, Canto ND, Valenti R, Gennari C, Nuti R. Longitudinal association between sex hormone levels, bone loss, and bone turnover in elderly men. J Clin Endocrinol Metab. 2003; 88:5327-5333. [PubMed: 14602769]

50. Khosla S, Melton LJ III, Robb RA, Camp JJ, Atkinson EJ, Oberg AL, Rouleau PA, Riggs BL. Relationship of volumetric BMD and structural parameters at different skeletal sites to sex steroid levels in men. J Bone Miner Res. 2005; 20:730-740. [PubMed: 15824845]

51. Khosla S, Amin S, Singh RJ, Atkinson EJ, Melton LJ, Riggs BL. Comparison of sex steroid measurements in men by immunoassay versus mass spectroscopy and relationships with cortical and trabecular volumetric bone mineral density. Osteoporos Int. 2008; 19:1465-1471. [PubMed: 18338096]

52. Falahati-Nini A, Riggs BL, Atkinson EJ, O'Fallon WM, Eastell R, Khosla S. Relative contributions of testosterone and estrogen in regulating bone resorption and formation in normal elderly men. $\mathrm{J}$ Clin Invest. 2000; 106:1553-1560. [PubMed: 11120762]

53. Leder BZ, LeBlanc KM, Schoenfeld DA, Eastell R, Finkelstein JS. Differential effects of androgens and estrogens on bone turnover in normal men. J Clin Endocrinol Metab. 2003; 88:204210. [PubMed: 12519853]

54. Kasai R, Bianco P, Robey PG, Kahn AJ. Production and characterization of an antibody against the human bone GLA protein (BGP/osteocalcin) propeptide and its use in immunocytochemistry of bone cells. Bone Miner. 1994; 25:167-182. [PubMed: 8086856]

55. Lian JB, Stein GS, Canalis E, Gehron Robey P, Boskey AL. Bone formation: osteoblast lineage cells, growth factors, matrix proteins, and the mineralization process. Primer on the Metabolic Bone Diseases and Disorders of Mineral Metabolism. 1999; 3:14-29.

56. Amin S, Zhang Y, Felson DT, Sawin CT, Hannan MT, Wilson PWF, Kiel DP. Estradiol, testosterone, and the risk for hip fractures in elderly men from the Framingham Study. The American journal of medicine. 2006; 119:426-433. [PubMed: 16651055]

57. Meier C, Nguyen TV, Handelsman DJ, Schindler C, Kushnir MM, Rockwood AL, Meikle AW, Center JR, Eisman JA, Seibel MJ. Endogenous sex hormones and incident fracture risk in older men. Arch Intern Med. 2008; 168:47-54. [PubMed: 18195195]

58. Mellstrom D, Vandenput L, Mallmim H, Holmberg AH, Lorentzon M, Oden A, Johansson H, Orwoll E, Labrie F, Karlsson MK, Ljunggren O, Ohlsson C. Older men with low serum estradiol and high serum SHBG have an increased risk of fractures. J Bone Miner Res. 2008; 23:15521560. [PubMed: 18518773]

59. Leblanc ES, Nielson CM, Marshall LM, Lapidus JA, Barrett-Connor E, Ensrud KE, Hoffman AR, Laughlin G, Ohlsson C, Orwoll ES. Group OFiMMS. The effects of serum testosterone, estradiol, and sex hormone binding globulin levels on fracture risk in older men. J Clin Endocrinol Metab. 2009; 94:3337-3346. [PubMed: 19584177]

60. Sun L, Peng Y, Sharrow AC, Iqbal J, Zhang Z, Papachristou DJ, Zaidi S, Zhu LL, Yaroslavskiy BB, Zhou H, Zallone AZ, Sairam MR, Kumar TR, Bo W, Braun JJ, Cardoso-Landa L, Schaffler MB, Moonga BS, Blair HC, Zaidi M. FSH directly regulates bone mass. Cell. 2006; 125:247-260. [PubMed: 16630814]

61. Sowers MFR, Jannausch M, McConnell D, Little RD, Greendale GA, Finkelstein JS, Neer RM, Johnston J, Ettinger B. Hormone predictors of bone mineral density changes during the menopausal transition. J Clin Endocrinal Metab. 2006; 91:1261-1267.

62. Gao J, Tiwari-Pandey R, Samadfam R, Yang Y, Miao D, Karaplis AC, Sairam MR, Goltzman D. Altered ovarian function affects skeletal homeostasis independent of the action of folliclestimulating hormone (FSH). Endocrinology. 2007; 148:2613-2621. [PubMed: 17332067]

63. Sanyal A, Hoey KA, Modder UI, Lamsam JL, McCready LK, Peterson JM, Achenbach SJ, Oursler MJ, Khosla S. Regulation of bone turnover by sex steroids in men. J Bone Miner Res. 2008; 23:705-714. [PubMed: 18086006] 
64. Perrien DS, Achenbach SJ, Bledsoe SE, Walser B, Suva LJ, Khosla DG. Bone turnover across the menopause transition: correlations with inhibins and follicle-stimulating hormone. J Clin Endocrinol Metab. 2006; 91:1848-1854. [PubMed: 16449331]

65. Gaddy-Kurten D, Coker JK, Abe E, Jilka RL, Manolagas SC. Inhibinsuppresses and activin stimulates osteoblastogenesis and osteoclastogenesis in murine bone marrow cultures. Endocrinology. 2002; 143:74-83. [PubMed: 11751595]

66. Haney EM, Chan BK, Diem SJ, Ensrud KE, Cauley JA, Barrett-Connor E, Orwoll E, Bliziotes MM. Group OFiMS. Association of low bone mineral density with selective serotonin reuptake inhibitor use by older men. Arch Intern Med. 2007; 167:1246-1251. [PubMed: 17592097]

67. Yadav VK, Ryu J-H, Suda N, Tanaka KF, Gingrich JA, Schutz G, Glorieux FH, Chiang CY, Zajac JD, Insogna KL, Mann JJ, Hen R, Ducy P, Karsenty G. Lrp5 controls bone formation by inhibiting serotonin synthesis in the duodenum. Cell. 2008; 135:825-837. [PubMed: 19041748]

68. Modder UI, Achenbach SJ, Amin S, Riggs BL, Melton LJ III, Khosla S. Relation of serum serotonin to bone density and structural parameters in women. J Bone Miner Res. in press.

69. Parfitt AM. Osteonal and hemi-osteonal remodeling: the spatial and temporal framework for signal traffic in adult human bone. J Cell Biochem. 1994; 55:273-286. [PubMed: 7962158]

70. Jilka RL, Takahashi K, Munshi M, Williams DC, Roberson PK, Manolagas SC. Loss of estrogen upregulates osteoblastogenesis in the murine bone marrow. J Clin Invest. 1998; 101:1942-1950. [PubMed: 9576759]

71. Gregorio GB, Yamamoto M, Ali AA, Abe E, Roberson P, Manolagas SC, Jilka RL. Attenuation of the self-renewal of transit-amplifying osteoblast progenitors in the murine bone marrow by 17 betaestradiol. J Clin Invest. 2001; 107:803-812. [PubMed: 11285299]

72. Bucay N, Sarosi I, Dunstan CR, Morony S, Tarpley J, Capparelli C, Scully S, Tan HL, Xu W, Lacey DL, Boyle WJ, Simonet WS. Osteoprotegerin-deficient mice develop early onset osteoporosis and arterial calcification. Genes Dev. 1998; 12:1260-1268. [PubMed: 9573043]

73. Eghbali-Fatourechi G, Khosla S, Sanyal A, Boyle WJ, Lacey DL, Riggs BL. Role of RANK ligand in mediating increased bone resorption in early postmenopausal women. J Clin Invest. 2003; 111:1221-1230. [PubMed: 12697741]

74. Hsu H, Lacey DL, Dunstan CR, Solovyev I, Colombero A, Timms E, Tan HL, Elliott G, Kelley MJ, Sarosi I, Wang L, Xia XZ, Elliott R, Chiu L, Black T, Scully S, Capparelli C, Morony S, Shimamoto G, Bass MB, Boyle WJ. Tumor necrosis factor receptor family member RANK mediates osteoclast differentiation and activation induced by osteoprotegerin ligand. Proc Natl Acad Sci USA. 1999; 96:3540-3545. [PubMed: 10097072]

75. Simonet WS, Lacey DL, Dunstan CR, Kelley M, Chang MS, Luthy R, Nguyen HQ, Wooden S, Bennett L, Boone T, Shimamoto G, DeRose M, Elliott R, Colombero A, Tan HL, Trail G, Sullivan J, Davy E, Bucay N, Renshaw-Gegg L, Hughes TM, Hill D, Pattison W, Campbell P. Osteoprotegerin: a novel secreted protein involved in the regulation of bone density. Cell. 1997; 89:309-319. Notes aa. [PubMed: 9108485]

76. Hofbauer LC, Khosla S, Dunstan CR, Lacey DL, Spelsberg TC, Riggs BL. Estrogen stimulates gene expression and protein production of osteoprotegerin in human osteoblastic cells. Endocrinology. 1999; 140:4367-4370. [PubMed: 10465311]

77. Khosla S, Atkinson EJ, Dunstan CR, O'Fallon WM, Riggs BL. Estrogen and testosterone have opposite effects on circulating OPG levels following induction of hypogonadism and aromatase inhibition in normal elderly men: potential mechanism for differential effects of estrogen versus testosterone on bone resorption. J Bone Miner Res. 2001; 16(Suppl 1):S146.

78. Kawano H, Sato T, Yamada T, Matsumoto T, Sekine K, Watanabe T, Nakamura T, Fukuda T, Yoshimura K, Yoshizawa T, Aihara Ki, Yamamoto Y, Nakamichi Y, Maetzger D, Chambon P, Nakamura K, Kawaguchi H, Kato S. Suppressive function of androgen receptor in bone resorption. Proc Natl Acad Sci USA. 2003; 100:9416-9421. [PubMed: 12872002]

79. Manolagas SC, Jilka RL. Bone marrow, cytokines, and bone remodeling: Emerging insights into the pathophysiology of osteoporosis. N Engl J Med. 1995; 332:305-311. [PubMed: 7816067]

80. Pacifici R, Brown C, Puscheck E, Friedrich E, Slatopolsky E, Maggio D, McCracken R, Avioli LV. Effect of surgical menopause and estrogen replacement on cytokine release from human blood mononuclear cells. Proc Natl Acad Sci USA. 1991; 88:5134-5138. [PubMed: 2052592] 
81. Tanaka S, Takahashi N, Udagawa N, Tamura T, Akatsu T, Stanley ER, Kurokawa T, Suda T. Macrophage colony-stimulating factor is indispensable for both proliferation and differentiation of osteoclast progenitors. J Clin Invest. 1993; 91:257-263. [PubMed: 8423223]

82. Kimble RB, Vannice JL, Bloedow DC, Thompson RC, Hopfer W, Kung VT, Brownfield C, Pacifici R. Interleukin-1 receptor antagonist decreases bone loss and bone resorption in ovariectomized rats. J Clin Invest. 1994; 93:1959-1967. [PubMed: 8182127]

83. Ammann P, Rizzoli R, Bonjour J, Bourrin S, Meyer J, Vassalli P, Garcia I. Transgenic mice expressing soluble tumor necrosis factor-receptor are protected against bone loss caused by estrogen deficiency. J Clin Invest. 1997; 99:1699-1703. [PubMed: 9120014]

84. Kimble RB, Srivastava S, Ross FP, Matayoshi A, Pacifici R. Estrogen deficiency increases the ability of stromal cells to support murine osteoclastogenesis via an interleukin-1-and tumor necrosis factor-mediated stimulation of macrophage colony-stimulating factor production. J Biol Chem. 1996; 271:28890-28897. [PubMed: 8910536]

85. Kitazawa R, Kimble RB, Vannice JL, Kung VT, Pacifici R. Interleukin-1 receptor antagonist and tumor necrosis factor binding protein decrease osteoclast formation and bone resorption in ovariectomized mice. J Clin Invest. 1994; 94:2397-2406. [PubMed: 7989596]

86. Girasole G, Jilka RL, Passeri G, Boswell S, Boder G, Williams DC, Manolagas SC. 17betaEstradiol inhibits interleukin- 6 production by bone marrow-derived stromal cells and osteoblasts in vitro: A potential mechanism for the antiosteoporotic effect of estrogens. J Clin Invest. 1992; 89:883-891. [PubMed: 1541679]

87. Jilka RL, Hangoc G, Girasole G, Passeri G, Williams DC, Abrams JS, Boyce B, Broxmeyer H, Manolagas SC. Increased osteoclast development after estrogen loss: Mediation by interleukin-6. Science. 1992; 257:88-91. [PubMed: 1621100]

88. Oursler MJ, Cortese C, Keeting P, Riggs BL, Spelsberg TC. Modulation of TGF-beta and mRNA levels in normal human osteoblast-like cells by 17 beta-estradiol and PTH. J Bone Miner Res. 1991; 6(Suppl 1):S257.

89. Hughes DE, Dai A, Tiffee JC, Li HH, Mundy GR, Boyce BF. Estrogen promotes apoptosis of murine osteoclasts mediated by TGF-beta. Nat Med. 1996; 2:1132-1136. [PubMed: 8837613]

90. Chen Q, Kaji H, Sugimoto T, Chihara K. Testosterone inhibits osteoclast formation stimulated by parathyroid hormone through androgen receptor. FEBS Lett. 2001; 491:91-93. [PubMed: 11226426]

91. Shevde NK, Bendixen AC, Dienger KM, Pike JW. Estrogens suppress RANK ligand-induced osteoclast differentiation via a stromal cell independent mechanism involving c-Jun repression. Proc Natl Acad Sci USA. 2000; 97:7829-7834. [PubMed: 10869427]

92. Huber DM, Bendixen AC, Pathrose P, Srivastava S, Dienger KM, Shevde NK, Pike JW. Androgens suppress osteoclast formation induced by RANKL and macrophage-colony stimulating factor. Endocrinology. 2001; 142:3800-3808. [PubMed: 11517156]

93. Srivastava S, Toraldo G, Weitzmann MN, Cenci S, Ross FP, Pacifici R. Estrogen decreases osteoclast formation by down-regulating receptor activator of NF-kB ligand (RANKL)-induced JNK activation. J Biol Chem. 2001; 276:8836-8840. [PubMed: 11121427]

94. Oursler MJ, Judd JW, Riggs BL, Spelsberg TC. Osteoclasts respond to estrogen treatment by increased TGF-beta protein production. J Bone Miner Res. 1994; 9(Suppl 1):S178.

95. Pederson L, Kremer M, Judd J, Pascoe D, Spelsberg TC, Riggs BL, Oursler MJ. Androgens regulate bone resorption activity of isolated osteoclasts in vitro. Proc Natl Acad Sci USA. 1999; 96:505-510. [PubMed: 9892663]

96. Nakamura T, Imai Y, Matsumoto T, Sato S, Takeuchi K, Igarashi K, Harada Y, Azuma Y, Krust A, Yamamoto Y, Nishina H, Takeda S, Takayanagi H, Metzger D, Kanno J, Takaoka K, Martin TJ, Chambon P, Kato S. Estrogen prevents bone loss via estrogen receptor alpha and induction of fas ligand in osteoclasts. Cell. 2007; 130:811-823. [PubMed: 17803905]

97. Chang J, Wang Z, Tang E, Fan Z, McCauley L, Franceschi R, Guan K, Krebsbach PH, Wang C-Y. Inhibition of osteoblastic bone formation by nuclear factor-kappaB. Nat Med. 2009; 15:682-689. [PubMed: 19448637]

98. Kousteni S, Bellido T, Plotkin LI, O'Brien CA, Bodenner DL, Han L, Han K, DiGregorio GB, Katzenellenbogen JA, Katzenellenbogen BS, Roberson PK, Weinstein RS, Jilka RL, Manolagas 
SC. Nongenotropic, sex-nonspecific signaling through the estrogen or androgen receptors: dissociation from transcriptional activity. Cell. 2001; 104:719-730. [PubMed: 11257226]

99. Kousteni S, Han L, Chen JR, Almeida M, Plotkin LI, Bellido T, Manolagas SC. Kinase-mediated regulation of common transcription factors accounts for the bone-protective effects of sex steroids. J Clin Invest. 2003; 111:1651-1664. [PubMed: 12782668]

100. Ernst M, Heath JK, Rodan GA. Estradiol effects on proliferation, messenger ribonucleic acid for collagen and insulin-like growth factor-I, and parathyroid hormone-stimulated adenylate cyclase activity in osteoblastic cells from calvariae and long bones. Endocrinology. 1989; 125:825-833. [PubMed: 2752978]

101. Gray TK, Mohan S, Linkhart TA, Baylink DJ. Estradiol stimulates in vitro the secretion of insulin-like growth factors by the clonal osteoblastic cell line, UMR106. Biochem Biophys Res Commun. 1989; 158:407-412. [PubMed: 2916989]

102. Okazaki R, Inoue D, Shibata M, Saika M, Kido S, Ooka H, Tomiyama H, Sakamoto Y, Matsumoto T. Estrogen promotes early osteoblast differentiation and inhibits adipocyte differentiation in mouse bone marrow stromal cell lines that express estrogen receptor (ER) alpha or beta. Endocrinology. 2002; 143:2349-2356. [PubMed: 12021200]

103. Dang ZC, Van Bezooijen RL, Karperien M, Papapoulos SE, Lowik CWGM. Exposure of KS483 cells to estrogen enhances osteogenesis and inhibits adipogenesis. J Bone Miner Res. 2002; 17:394-405. [PubMed: 11878304]

104. Tomkinson A, Reeve J, Shaw RW, Noble BS. The death of osteocytes via apoptosis accompanies estrogen withdrawal in human bone. J Clin Endocrinol Metab. 1997; 82:3128-3135. [PubMed: 9284757]

105. Pitsillides AA, Rawlinson SCF, Suswillo RFL, Bourrin S, Zaman G, Lanyon LE. Mechanical strain-induced NO production by bone cells: a possible role in adaptive bone (re)modelling. FASEB J. 1995; 9:1614-1622. [PubMed: 8529841]

106. Gray C, Colston KW, Mackay AG, Taylor ML, Arnett TR. Interaction of androgen and 1,25dihydroxyvitamin D3: Effects on normal rat bone cells. J Bone Miner Res. 1992; 7:41-46. [PubMed: 1549957]

107. Kasperk CH, Wergedal JE, Farley JR, Linkhart TA, Turner RT, Baylink DJ. Androgens directly stimulate proliferation of bone cells in vitro. Endocrinology. 1989; 124:1576-1578. [PubMed: 2521824]

108. Benz DJ, Haussler MR, Thomas MA, Speelman B, Komm BS. High-affinity androgen binding and androgenic regulation of alpha1(I)-procollagen and transforming growth factor-beta steady state messenger ribonucleic acid levels in human osteoblast-like osteosarcoma cells. Endocrinology. 1991; 128:2723-2730. [PubMed: 2036957]

109. Hofbauer LC, Hicok KC, Khosla S. Effects of gonadal and adrenal androgens in a novel androgen-responsive human osteoblastic cell line. J Cell Biochem. 1998; 71:96-108. [PubMed: 9736458]

110. Kasperk CH, Faehling K, Borcsok I, Ziegler R. Effects of androgens on subpopulations of the human osteosarcoma cell line SaOS2. Calcif Tissue Int. 1996; 58:376-382. [PubMed: 8661974]

111. Kasperk CH, Wakley GK, Hierl T, Ziegler. Gonadal and adrenal androgens are potent regulators of human bone cell metabolism in vitro. J Bone Miner Res. 1997; 12:464-471. [PubMed: 9076590]

112. Pilbeam CC, Raisz LG. Effects of androgens on parathyroid hormone and interleukin-1stimulated prostaglandin production in cultured neonatal mouse calvariae. J Bone Miner Res. 1990; 5:1183-1188. [PubMed: 2270781]

113. Kasperk C, Fitzsimmons R, Strong D, Mohan S, Jennings J, Wergedal J, Baylink D. Studies of the mechanism by which androgens enhance mitogenesis and differentiation in bone cells. J Clin Endocrinol Metab. 1990; 71:1322-1329. [PubMed: 2229290]

114. Gori F, Hofbauer LC, Conover CA, Khosla S. Effects of androgens on the insulin-like growth factor system in an androgen-responsive human osteoblastic cell line. Endocrinology. 1999; 140:5579-5586. [PubMed: 10579321]

115. Khosla S, Westendorf JJ, Oursler MJ. Building bone to reverse osteoporosis and repair fractures. J Clin Invest. 2008; 118:421-428. [PubMed: 18246192] 
116. Almeida M, Martin-Millan M, Plotkin LI, Stewart SA, Roberson PK, Kousteni S, O'Brien CA, Bellido T, Parfitt AM, Weinstein RS, Jilka RL, Manolagas SC. Skeletal involution by ageassociated oxidative stress and its acceleration by loss of sex steroids. J Biol Chem. 2007; 282:27285-27297. [PubMed: 17623659]

117. Finkel T, Deng CX, Mostoslavsky R. Recent progress in the biology and physiology of sirtuins. Nature. 2009; 460:587-591. [PubMed: 19641587]

118. Edwards JR, Zainabadi K, Elefteriou E, Connelly L, Yull F, Blackwell TS, Alt F, Guarente L, Mundy GR. The aging associated gene SIRT-1 regulates osteoclast formation and bone mass in vivo. J Bone Miner Res. 2007; 22:S29.

119. Edwards JR, Zainabadi K, Lwin ST, Elefteriou E, Munoz S, Moore MM, Guarente L, Mundy GR. The longevity genen SIRT-1 independently controls both osteoblast and osteoclast function. J Bone Miner Res. 2008; 23:S28.

120. Baur JA, Pearson KJ, Price NL, Jamieson HA, Lerin C, Kalra A, Prabhu VV, Allard JS, LopezLluch G, Lewis K, Pistell PJ, Poosala S, Becker KG, Boss O, Gwinn D, Wang M, Ramaswamy S, Fishbein KW, Spencer RG, Lakatta EG, Le Couteur D, Shaw RJ, Navas P, Puigserver P, Ingram DK, de Cabo R, Sinclair DA. Resveratrol improves health and survival of mice on a high-calorie diet. Nature. 2006; 444:337-342. [PubMed: 17086191]

121. Su JL, Yang CY, Zhao M, Kuo ML, Yen ML. Forkhead proteins are critical for bone morphogenetic protein-2 regulation and anti-tumor activity of resveratrol. J Biol Chem. 2007; 282:19385-19398. [PubMed: 17513867]

122. Campisi J, d'Adda di Fagagna F. Cellular senescence: when bad things happen to good cells. Nat Rev Mol Cell Biol. 2007; 8:729-740. [PubMed: 17667954]

123. Riggs BL, Melton LJ. Medical progress series: Involutional osteoporosis. N Engl J Med. 1986; 314:1676-1686. [PubMed: 3520321]

124. Lowe, H.; Shane, E. Osteoporosis associated with illnesses and medications. In: Marcus, R.; Feldman, D.; Nelson, DA.; Rosen, CJ., editors. Osteoporosis. Third ed. San Diego, CA: Elsevier Press; 2007. p. 1283-1314.

125. Syed F, Khosla S. Mechanisms of sex steroid effects on bone. Biochem Biophys Res Commun. 2005; 328:688-696. [PubMed: 15694402] 


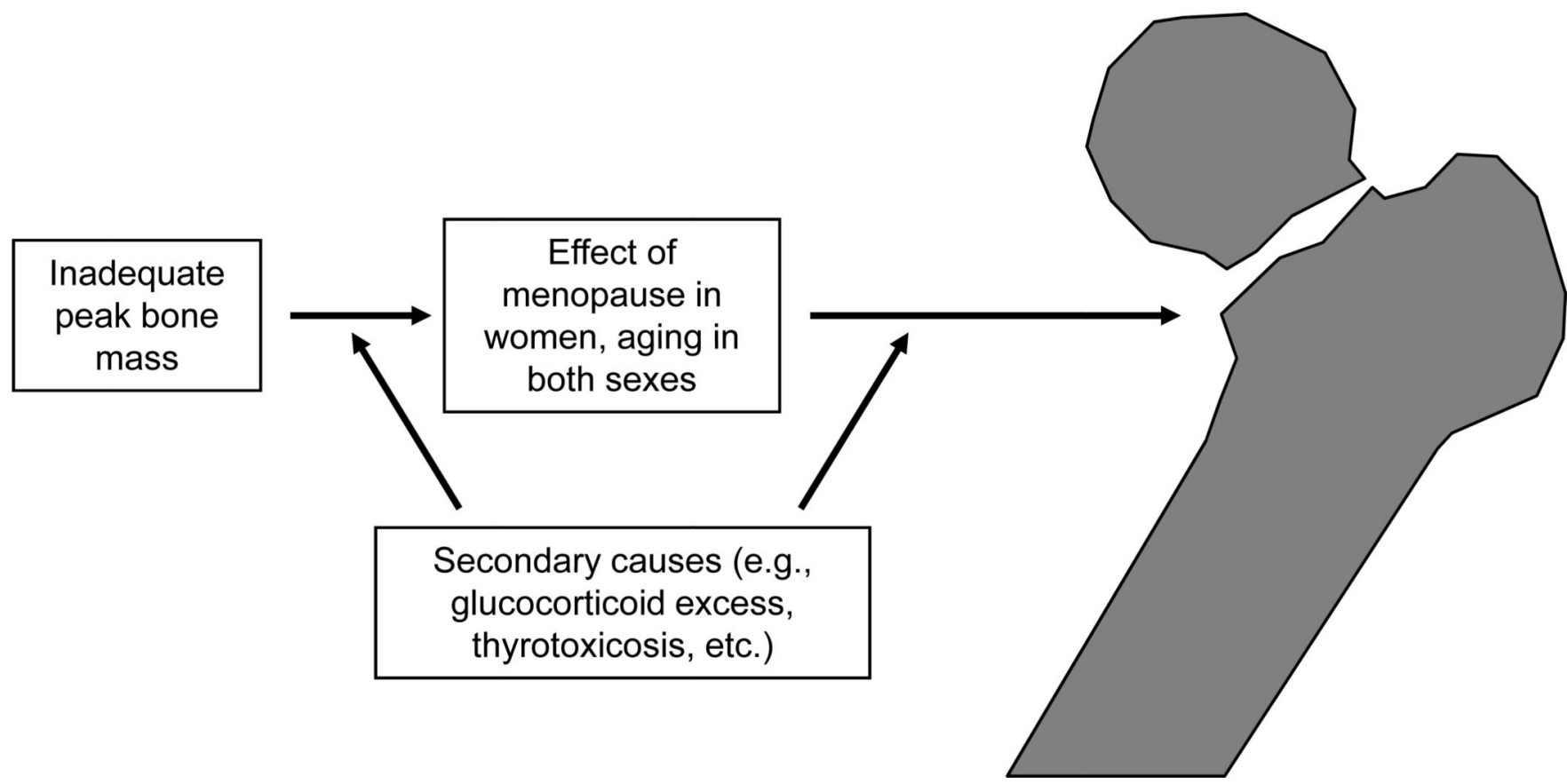

Figure 1.

Overall schematic for the pathogenesis of osteoporosis. Please see text for details. 


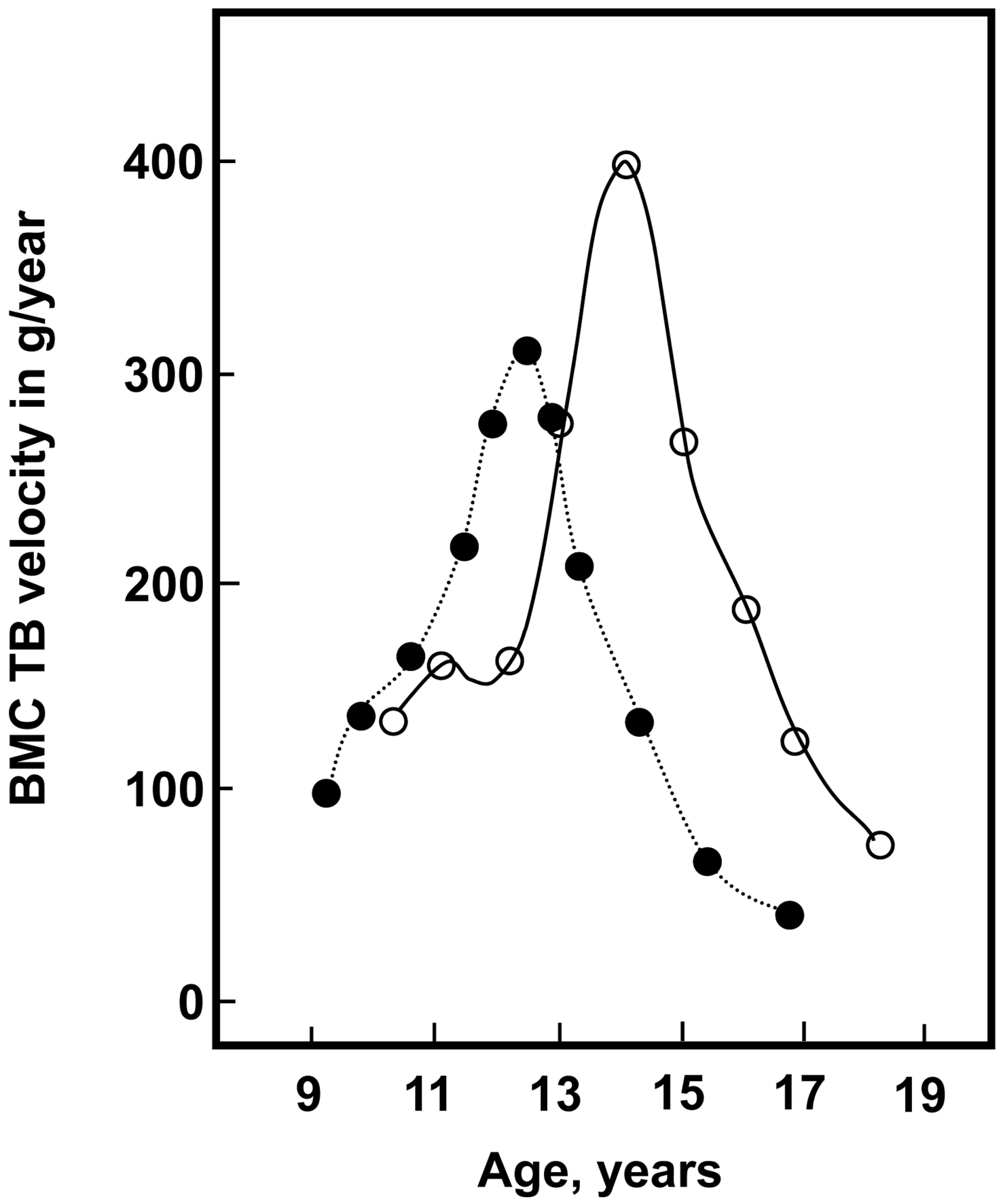

Figure 2.

Bone mineral content (BMC) in the total body (TB) accrual in boys (open circles) and girls (closed circles). Reproduced from Bailey et al. (6), with permission. 

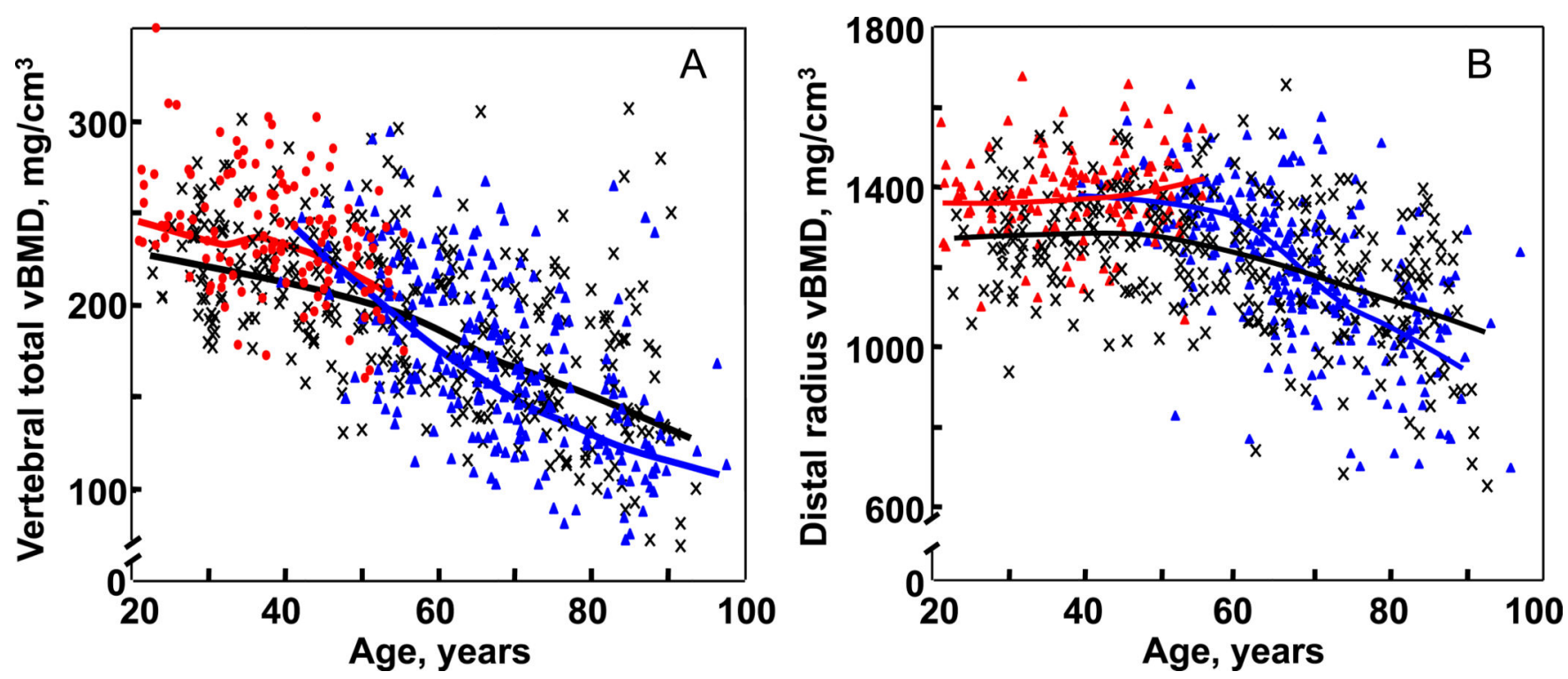

Figure 3.

(A) Values for $\mathrm{vBMD}\left(\mathrm{mg} / \mathrm{cm}^{3}\right)$ of the total vertebral body in a population sample of Rochester, Minnesota women and men between the ages of 20 and 97 years. Individual values and smoother lines are given for premenopausal women in red, for postmenopausal women in blue, and for men in black. (B) Values for cortical vBMD at the distal radius in the same cohort. Color code is as in Panel A. All changes with age were significant $(\mathrm{P}<$ 0.05). Reproduced from Riggs et al. (16), with permission. 
Perl MP (n=45)

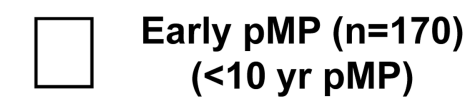

(<10 yr pMP)

Late pMP $(n=262)$

( $\geq 10$ yr pMP)

${ }^{* *} \mathrm{P}<0.01,{ }^{* * *} \mathrm{P}<0.001$ vs pre MP
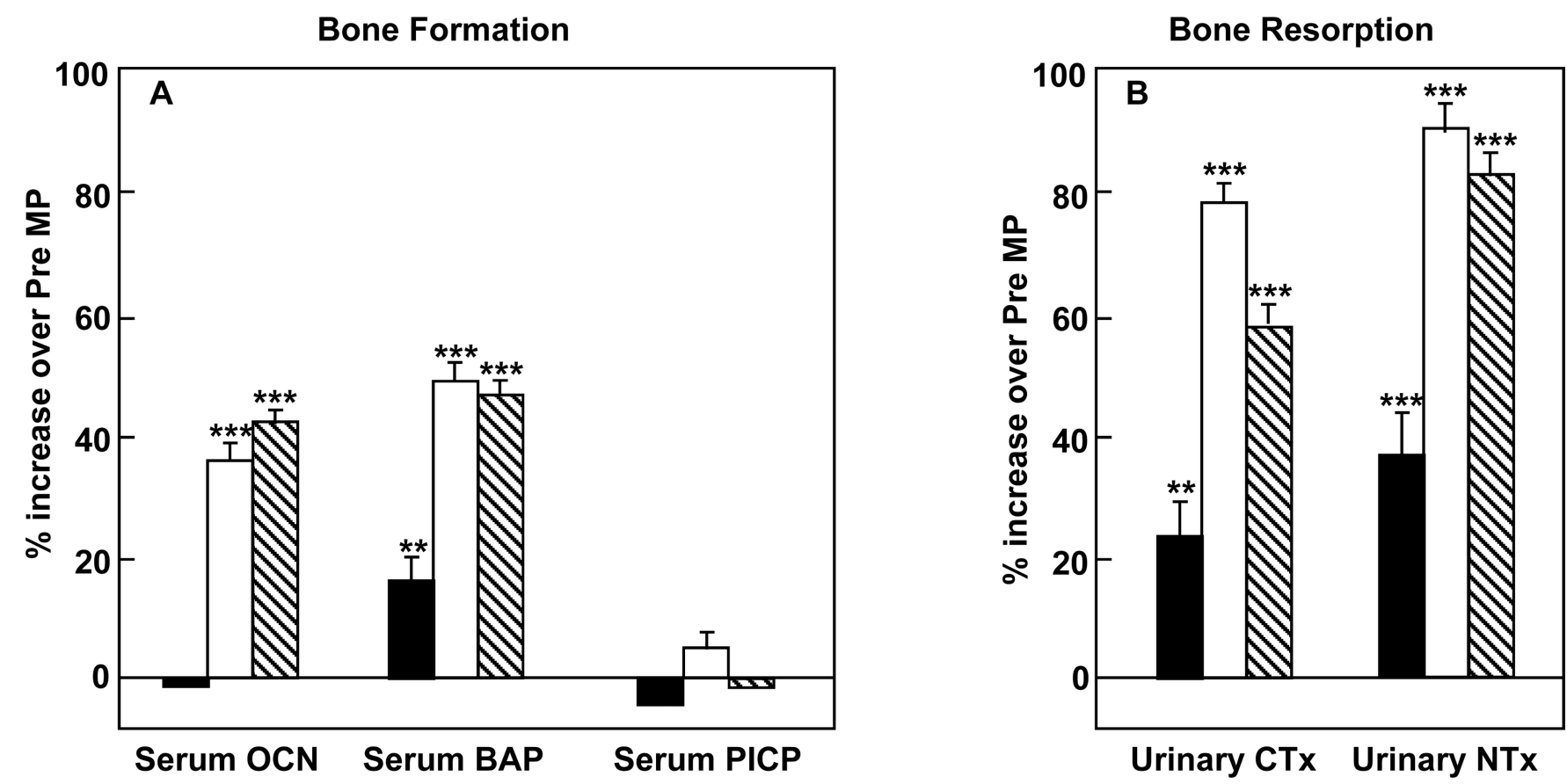

Figure 4.

Bone formation (serum osteocalcin [OCN], bone alkaline phosphatase [BAP] and Cterminal propeptide of type I collagen [PICP]) and bone resorption (urinary C-telopeptide of type I collagen [CTx] and N-telopeptide of type I collagen [NTx]) markers in perimenopausal (peri MP), early postmenopausal (Early pMP), and late postmenopausal (Late pMP) women. Reproduced from Garnero et al. (35), with permission. 


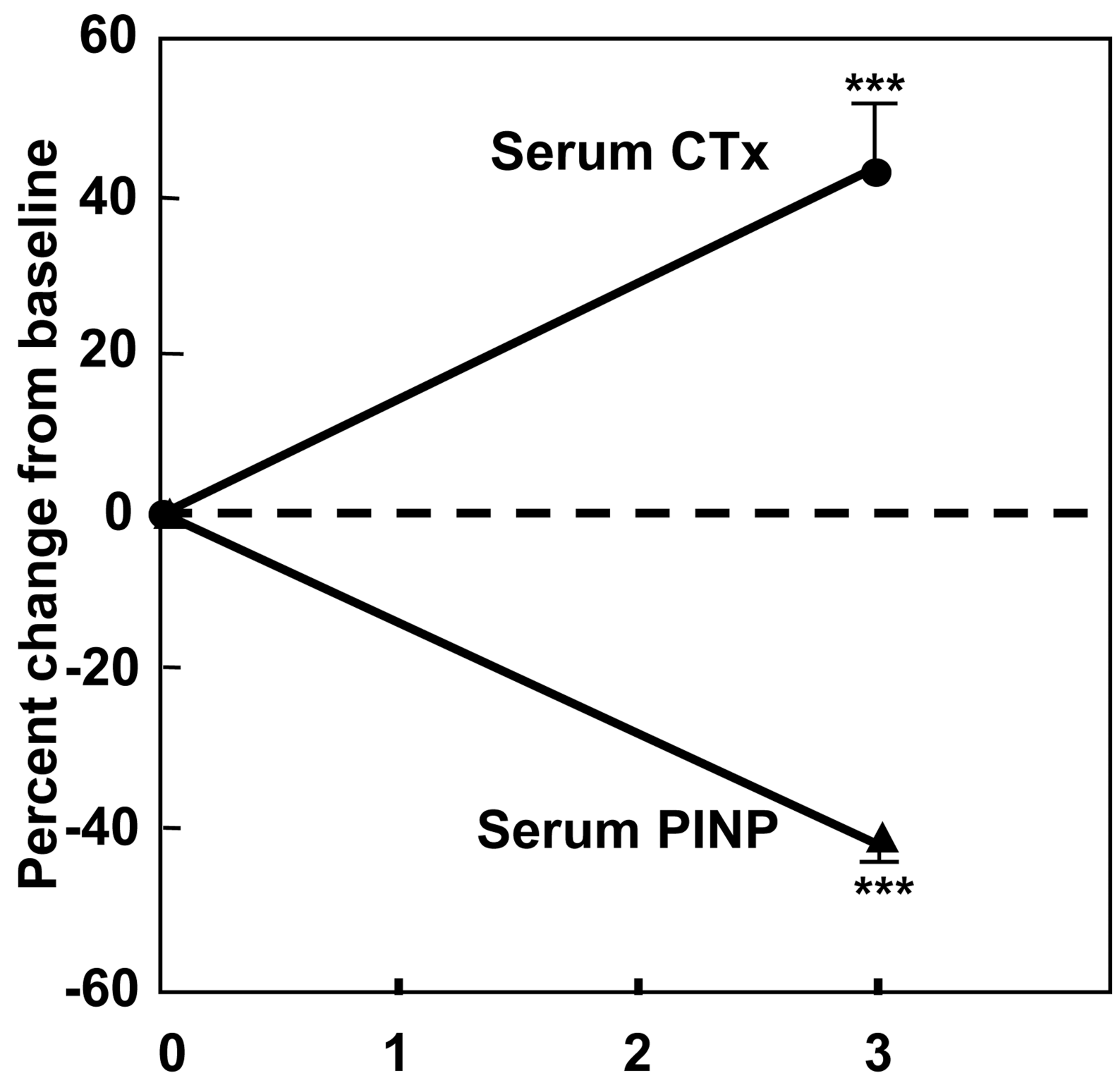

\section{Duration of sex steroid deficiency, weeks}

Figure 5.

(A) Short term increase in the bone resorption marker, serum C-telopeptide of type I collagen (CTx) and decrease in the bone formation marker, serum $\mathrm{N}$-terminal propeptide of type I collagen (PINP) following the acute induction of estrogen deficiency in postmenopausal women (adapted from (36)). ***P $<0.001$. 


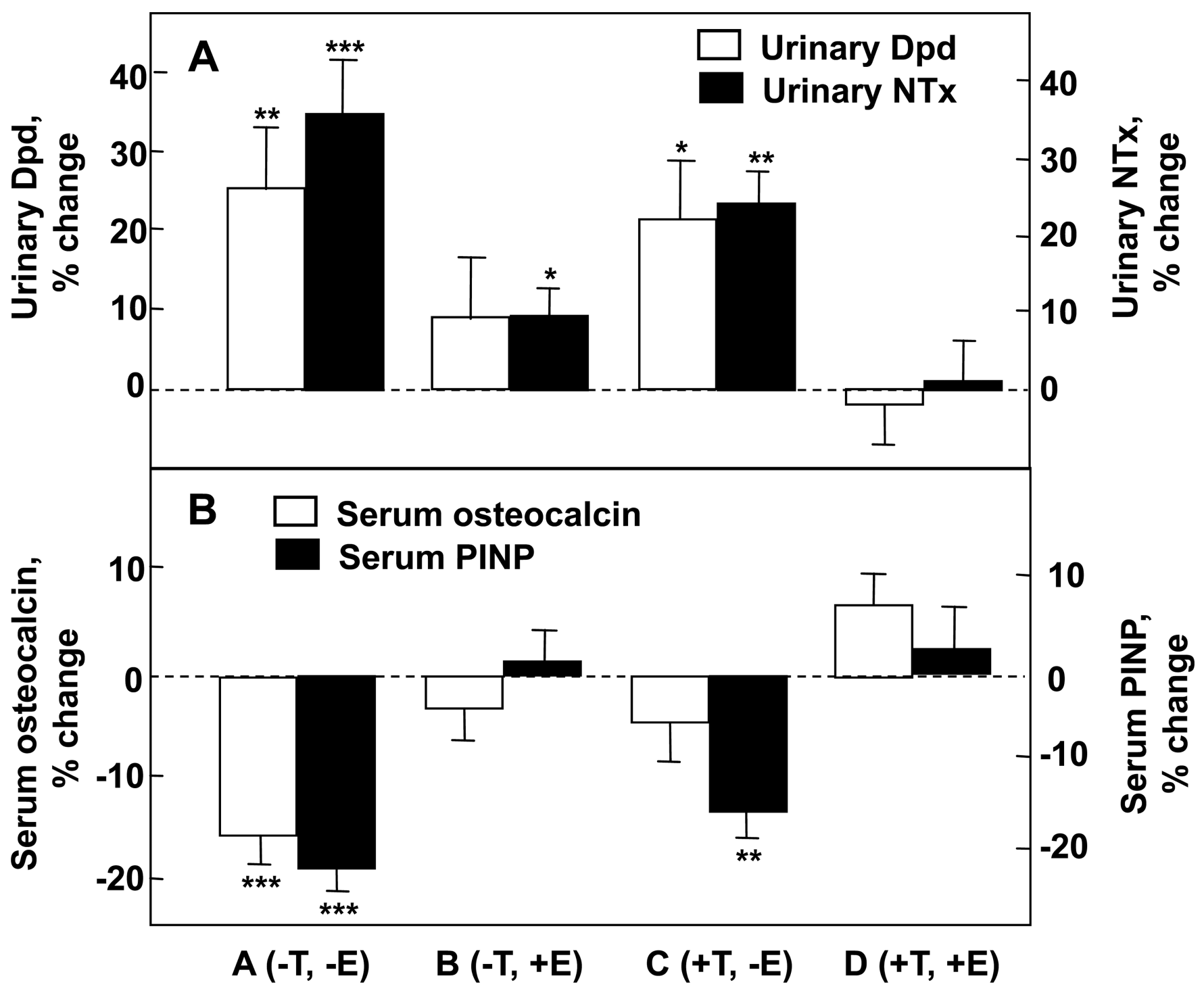

Figure 6.

Percent changes in (A) bone resorption markers (urinary deoxypyridinoline [Dpd] and Ntelopeptide of type I collagen [NTx]) and (B) bone formation markers (serum osteocalcin and $\mathrm{N}$-terminal extension peptide of type I collagen [PINP]) in a group of elderly men (mean age $68 \mathrm{yrs}$ ) made acutely hypogonadal and treated with an aromatase inhibitor (Group A), treated with estrogen alone (Group B), testosterone alone (Group C), or both (Group D). See text for details. Asterisks indicate significance for change from baseline: *, P < 0.05; **, P < 0.01 ; **, $\mathrm{P}<0.001$. Adapted from Falahati-Nini et al. (52), with permission. 


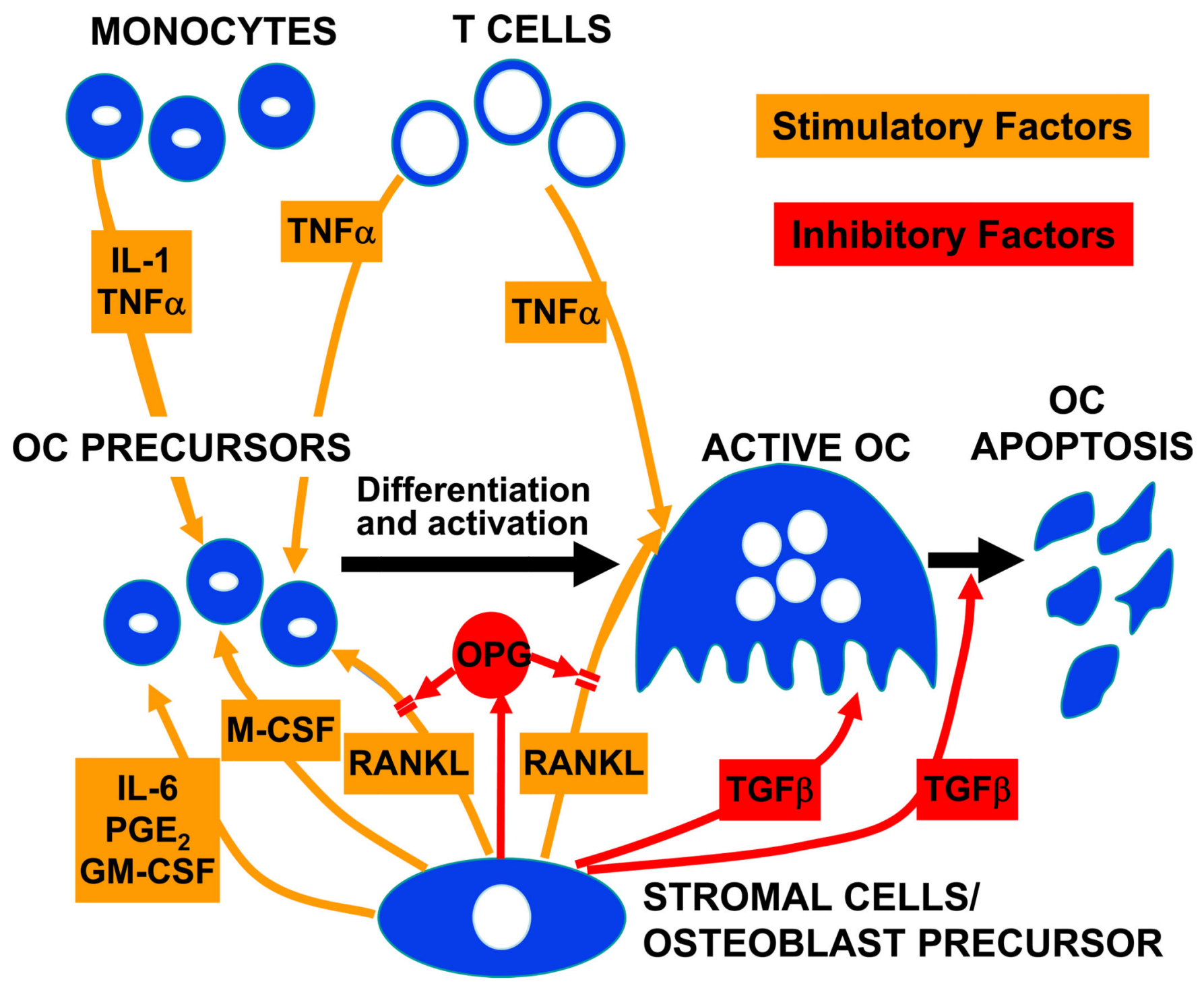

Figure 7.

Summary of stimulatory and inhibitory factors involved in osteoclast (OC) development and apoptosis. Please see text for details. Reproduced from (125), with permission. 


\title{
Table 1
}

Secondary causes of osteoporosis (from Lowe et al. (124), with permission)

\author{
Genetic disorders \\ Ehlers-Danlos \\ Glycogen storage diseases \\ Gaucher's disease \\ Hemochromatosis \\ Homocystinuria \\ Hypophosphatasia \\ Marfan's syndrome \\ Menkes steely hair syndrome \\ Osteogenesis Imperfecta \\ Porphyria \\ Riley-Day syndrome \\ Hypogonadal states \\ Androgen insensitivity \\ Anorexia nervosa/bulimia \\ Athletic amenorrhea \\ Hyperprolactinemia \\ Panhypopituitarism \\ Premature menopause \\ Turner's and Kleinfelter's syndrome \\ Endocrine disorders \\ Acromegaly \\ Adrenal insufficiency \\ Cushing's syndrome \\ Diabetes mellitus \\ Hyperparathyroidism $\left(1^{\circ}\right.$ and $\left.2^{\circ}\right)$ \\ Thyroid disease \\ Gastrointestinal disorders \\ Gastrectomy \\ Inflammatory bowel disease \\ Malabsorption \\ Celiac disease \\ Primary biliary cirrhosis \\ Hematologic disorders \\ Sickle cell disease \\ Thalassemia \\ Hemophilia \\ Multiple myeloma \\ Leukemias and lymphoma \\ Systemic mastocytosis
}


Genetic disorders

Rheumatologic diseases

Ankylosing spondylitis

Rheumatoid arthritis

Nutritional deficiencies

Calcium

Magnesium

Vitamin D

Drugs

Anticoagulants (heparin and warfarin)

Anticonvulsants

Cyclosporines and tacrolimus

Cytotoxic drugs

Glucocorticoids (and ACTH)

Gonadotrophin-releasing hormone agonists

Lithium

Methotrexate

Antidepressants

Thyroxine

Miscellaneous

Alcoholism

Amyloidosis

Chronic metabolic acidosis

Congestive heart failure

Cystic fibrosis

Emphysema

Idiopathic hypercalciuria

Idiopathic scoliosis

Immobilization

Multiple sclerosis

Organ transplantation

Parenteral nutrition

Sarcoidosis 